\title{
ISONOMY, AUSTERITY, AND THE RIGHT TO ChOOSE COUNSEL
}

\author{
JANET MOORE*
}

\begin{abstract}
People who can afford to hire criminal defense attorneys have a Sixth Amendment right to choose a lawyer who is qualified, available, and free from conflicts of interest. The same right to choose counsel is routinely denied to people who need government-paid defense lawyers because they cannot afford to hire attorneys. In prior work, I invoked democratic theory to argue that this de jure discrimination blocks constitutional law formation by poor people and should be eliminated. This Article extends the analysis by explaining how a different theoretical approach-one grounded in libertarian commitments to private enterprise and austerity in public funding - shaped the nation's first pilot study on counsel choice in a public defense setting. Those commitments sharply limited the measure of counsel choice offered and left the study with insufficient data to support generalizable conclusions. Thus, the study underscores questions about whether an equal right of counsel choice can be meaningful under conditions of austerity and might actually aggravate instead of ameliorate system deficits. The Article concludes that while meaningful counsel choice for poor people may be elusive, the constitutional interests at stake nevertheless warrant elimination of overt class-based discrimination from the vindication of a fundamental right.
\end{abstract}

\section{INTRODUCTION}

People who need public defense lawyers are routinely denied the same Sixth Amendment right to choose counsel that is enjoyed by the minority of defendants who can afford to hire counsel. ${ }^{1}$ Courts and commentators often cite Supreme Court case law as requiring this "no choice for the poor" stance. ${ }^{2}$ That stance has even shaped international law; the U.S. Senate invoked it to justify excluding counsel choice from ratified provisions in the International Covenant on Civil and Political Rights. ${ }^{3}$

* Professor of Law, University of Cincinnati College of Law. Email: janet.moore@uc.edu. For invaluable feedback, I thank members of the Indigent Defense Research Association and am particularly grateful to Jim Bethke, Andy Davies, Lauryn Gouldyn, John Gross, Norm Lefstein, Elaine Nugent-Borakove, Anna Roberts, John Rappaport, Ron Wright, and faculty at the University of Cincinnati College of Law. Special thanks to Dean Lefstein and the Indiana University-Robert H. McKinney School of Law for sponsoring this symposium and to the editors of Indiana Law Review for their help in improving this Article. David Wovrosh provided excellent research assistance. Any errors are my own.

1. Janet Moore, The Antidemocratic Sixth Amendment, 91 Wash. L. ReV. 1705, 1706 (2016).

2. Id. at 1731-32.

3. Kristina Ash, U.S. Reservations to the International Covenant on Civil and Political

http://doi.org/10.18060/4806.1186 
In a prior article, I challenged the "no choice for the poor" stance with new doctrinal, theoretical, and practical arguments that called for elimination of de jure discrimination in the enforcement of a fundamental constitutional right. ${ }^{4}$ The doctrinal arguments explained that the prevailing wisdom on Supreme Court precedent is mistaken. ${ }^{5}$ The theoretical arguments exposed the "no choice for the poor" stance as an antidemocratic concentration of judicial power that blocks poor people from constitutional law formation. ${ }^{6}$ The practical arguments sketched ways to make counsel choice meaningful for people who need government-paid counsel, including rights-information and community organizing strategies. ${ }^{7}$

This Article extends that analysis by explaining how a different theoretical approach - one grounded in libertarian commitments to private enterprise and austerity in public funding - shaped the nation's first pilot study on counsel choice in a public defense setting. The study was undertaken in Comal County, Texas, and the resulting report documents an intriguing public policy experiment. ${ }^{8}$ However, the commitment to austerity in public funding sharply limited the measure of counsel choice offered and left the study with insufficient data to support generalizable conclusions. Thus, the study underscores questions about whether counsel choice can be meaningful under conditions of austerity in already resource-poor public defense systems, and whether under those conditions counsel choice might actually aggravate instead of ameliorate system deficits.

These limitations and questions belie claims that, as a result of the work in Comal County, counsel choice has "been tested and evaluated" sufficiently to prove that "when market competition was introduced, the quality of legal representation improved." To be sure, the study shows that when people were

Rights: Credibility Maximization and Global Influence, 3 Nw. J. HuM. RTs. \ 1, \ 16-19 n.53 (2005) (citing Senate Comm. on Foreign Relations, Report on the InTERnAtional Covenant on Civil and Political Rights, S. Exec. Rep. No. 23, at 18-19 (102d Sess. 1992), reprinted in 31 I.L.M. 645 (1992)).

4. Moore, supra note 1, at 1731.

5. Id. at 1731-32.

6. Id. at 1707 .

7. Id. at 1708-09.

8. See generally M. Elaine Nugent-Borakove et Al., The Power of Choice: The IMPLICATIONS OF A SYSTEM WHERE INDIGENT DEFENDANTS CHOOSE THEIR OWN COUNSEL (2017), available at http://www.jmijustice.org/wp-content/uploads/2017/04/The-Power-of-Choice_29MAR-2017.pdf [https://perma.cc/43CC-PX5S].

9. Tim Lynch, To Reform Indigent Defense, Bring the Market In, NAT'L REVIEW (Apr. 19, 2017, 4:00 AM), http://www.nationalreview.com/article/446864/public-defenders-client-choice [https://perma.cc/Q4TK-6NGL]; Tim Lynch, Texas May Offer a Model for Missouri's Public Defender Crisis, Kan. CITY STAR (May 7, 2017, 8:30 PM), http://www.kansascity.com/opinion/ opn-columns-blogs/syndicated-columnists/article148964379.html [https://perma.cc/HSN9-9HWR]; Tim Lynch, Restoring Justice to All in Tennessee, USA TODAY (June 1, 2017, 7:00 AM), https://www.usatoday.com/story/opinion/2017/06/01/restoring-justice-all-tennessee/360435001/ [https://perma.cc/9RMA-2RPB]. Mr. Lynch is an adjunct scholar and former Director of the Project 

TO CHOOSE COUNSEL

offered a measure of choice regarding the identity of their government-paid criminal defense lawyers, a strong majority $(72 \%)$ opted to exercise that choice instead of having judges do so on their behalf. ${ }^{10}$ The study also claims that the limited measure of choice offered did not pose major administrative challenges. ${ }^{11}$ Such results should not be surprising, however. Prior research has demonstrated the psychosocial attractions of choice ${ }^{12}$ and choosing public defense counsel is the norm in several common law countries. ${ }^{13}$

Interesting and unanswered questions about the Comal County experiment include: Who were among the minority that chose not to choose counsel? Why did they do so? Did their reasons for opting out affect other conduct in the case - such as their level of engagement with counsel-in ways that influenced study data and any inferences that can be drawn from those data? What results would emerge over a time period longer than the twelve months during which the pilot study was implemented and evaluated? Additional questions arise from the study's report of an association between counsel choice and improved case outcomes. ${ }^{14}$ On closer examination, the same data from this time-limited pilot study tell a much grimmer tale about the quality of representation in a seriously under-resourced public defense system.

The following four-part discussion begins to unpack the foregoing questions and concerns by focusing on different theoretical approaches to analyzing counsel choice. Part I explains two points about using democratic theory to frame the analysis. Part I.A shows how grounding counsel choice analysis in democratic theory reveals that counsel choice can be a mode of grassroots constitutional lawmaking, which strengthens the substantive meaning of a fundamental criminal procedure right. Part I.B highlights the importance of such opportunities for grassroots lawmaking given the antidemocratic impacts of criminal legal systems.

Part II explains how the Comal County counsel choice project was shaped by libertarian theory and commitments to austerity in public funding. Part III explains how those commitments limited the meaning of counsel choice during project implementation as well as the data that were generated and the conclusions those data can support. Part IV discusses study findings and proposes avenues for further research. The Article concludes that although such research may be beneficial, and although the circumstances required to make counsel

on Criminal Justice at the Cato Institute, CATO INST., https://www.cato.org/people/tim-lynch [https://perma.cc/9DMW-C94H] (last visited Feb. 17, 2018). Mr. Lynch served on the Advisory Panel for the Comal County counsel choice pilot project in the latter capacity. See NugentBORAKOVE ET AL., supra note 8, at 57 app. C.

10. See Nugent-Borakove ET AL., supra note 8, at 11.

11. Id. at 14 .

12. Simona Botti \& Sheena S. Iyengar, The Dark Side of Choice: When Choice Impairs Social Welfare, 25 J. Pub. PoL'y \& MARketing 24, $25-26$ (2006).

13. Norman Lefstein, In Search of Gideon's Promise: Lessons from England and the Need for Federal Help, 55 Hastings L.J. 835, 915-16 (2004).

14. See Nugent-Borakove et AL., supra note 8, at 33. 
choice meaningful may be elusive, the constitutional interests at stake warrant prompt elimination of overt class-based discrimination from the vindication of a fundamental right.

\section{COUNSEL CHOICE AS GRASSROOTS LAWMAKING}

This Part explains how framing counsel choice within democratic theory reveals its potential as an avenue for grassroots formation of constitutional law. Part I.A summarizes the relevant law. Part I.B underscores the importance of democracy-enhancing opportunities such as counsel choice given the antidemocratic impacts of the carceral state.

\section{A. Counsel Choice and Constitutional Law Formation}

Because the Sixth Amendment right to counsel $1^{15}$ is "necessary to insure ... life and liberty"16 it is included among the constitutional rights that are deemed "fundamental." 17 People therefore may not be incarcerated for a criminal conviction unless they have either received or waived defense representation. ${ }^{18}$ If they are among the majority of defendants who cannot afford to hire counsel, ${ }^{19}$ they have the right to a government-paid lawyer. ${ }^{20}$

The Supreme Court has also held that the minority of people who can afford to hire private criminal defense counsel have a Sixth Amendment right to choose their lawyers. ${ }^{21}$ The right is restricted to lawyers who are qualified to handle the case, available to do so in a timely manner, and free from conflicts of interest. ${ }^{22}$ In dicta, the Court also has stated that poor people have no such right. ${ }^{23}$ As I have argued elsewhere, this "no choice for the poor" stance should be repudiated, not

15. U.S. CONST. amend. VI.

16. Johnson v. Zerbst, 304 U.S. 458, 462 (1938).

17. Kimmelman v. Morrison, 477 U.S. 365, 374 (1986).

18. Alabama v. Shelton, 535 U.S. 654, 658-59 (2002) (right applies to any case involving incarceration, including misdemeanors resulting in subsequently-revoked probation); Gideon v. Wainwright, 372 U.S. 335, 339-41, 345 (1963) (right incorporated against the states in felony cases under the Due Process Clause of the Fourteenth Amendment); Zerbst, 304 U.S. at 467-68 (absent a knowing and voluntary waiver, "failure to complete the court" by providing counsel for indigent defendants violates the Sixth Amendment and divests federal courts of jurisdiction).

19. See, e.g., Caroline Wolf Harlow, U.S. Dep't of Justice, Bureau of Justice Statistics Special Report: Defense Counsel in Criminal CASES 1 (2000), available at http://www.bjs.gov/index.cfm?ty=pbdetail\&iid=772 [http://perma.cc/54XC-TNMS] (estimating that eighty-two percent of criminal defendants facing felony charges cannot afford to hire counsel).

20. Gideon, 372 U.S. at 344.

21. United States v. Gonzalez-Lopez, 548 U.S. 140, 144 (2006).

22. Id. at 151-52. In addition, defendants may lose assets that they would otherwise use to hire counsel through forfeiture if those assets can be traced to criminal activity. See Luis v. United States, 136 S. Ct. 1083, 1089 (2016).

23. See, e.g., Montejo v. Louisiana, 556 U.S. 778, 784 (2009) (citing Gonzalez-Lopez, 548 U.S. at 151). 

TO CHOOSE COUNSEL

only because it is discriminatory but also because it is antidemocratic. ${ }^{24}$

I came to those arguments reluctantly. As a public defense attorney specializing in capital appeals and post-conviction cases, I never questioned the received wisdom that Supreme Court case law denied the right of counsel choice to poor people. That received wisdom made life easier. It removed what I saw as a distraction and additional source of stress in already fraught attorney-client relationships. The stressors were not solely from the life-or-death consequences of each case. Most of the people I represented had life histories, mental health issues, and prior experiences with government-paid defense counsel that led to their suspicion and distrust toward lawyers and criminal legal systems. Although I worked hard to overcome the "Public Pretender" stereotype, it was still comforting to believe that, absent a total breakdown in communication, my clients had no meaningful choice but to work with me.

Upon entering the legal academy, I was surprised to discover that the received wisdom on the Supreme Court's counsel-choice rulings was mistaken. ${ }^{25}$ It was also interesting to learn from the participatory defense movement how people who need public defense can use community organizing strategies to improve representation and case outcomes. ${ }^{26}$ It became clear that de jure discrimination in vindicating the right of counsel choice denigrates the agency of poor people, silences their individual and collective voices, and reinforces stereotypes of their dependence, irrationality, and incapacity. ${ }^{27}$

It also became clear that vindicating the right of counsel choice for poor people has a distinctive significance beyond that which other scholars have emphasized in framing choice as a free-market tool to reward good lawyers and drive bad ones out of business. ${ }^{28}$ That distinctive significance lies in the right's democracy-enhancing potential. My arguments therefore reframed the dominant theoretical approach to counsel-choice analysis, which centers on the pursuit of rational self-interest by autonomous individuals in a deregulated marketplace, ${ }^{29}$ and revealed the right's implications for grassroots formation of constitutional law.

To be sure, some courts and commentators have emphasized the importance of counsel choice for enhancing trust between criminal defense lawyers and the

24. See Moore, supra note 1, at 1707.

25. Id. at 1731-32.

26. Janet Moore et al., Make Them Hear You: Participatory Defense and the Struggle for Criminal Justice Reform, 78 ALB. L. REV. 1281, 1282-83 (2015) [hereinafter Participatory Defense].

27. $C f$. Michael Omi \& Howard Winant, Racial Formation in the United States 105 06 (3d ed. 2015) (discussing racialized processes of social stratification).

28. See Stephen J. Schulhofer, Client Choice for Indigent Criminal Defendants: Theory and Implementation, 12 OHIO ST. J. CRIM. L. 505, 544-56 (2015).

29. See, e.g., Kaley v. United States, 134 S. Ct. 1090, 1105-15 (2014) (Roberts, C.J., Breyer \& Sotomayor, JJ., dissenting); Schulhofer, supra note 28. 
people who need them. ${ }^{30}$ Nevertheless, most of the small body of scholarship on counsel choice applies some variation of a rational-choice, free-market framework. For example, Dean Norman Lefstein has argued that poor people in the United States are as capable of choosing their lawyers as are people in countries that do not inject judicial Yentas into attorney-client matchmaking. ${ }^{31}$ Other scholars argue that choice promotes autonomy, ${ }^{32}$ refute the idea that "beggars can't be choosers" by noting that most poor people contribute to the cost of their representation, ${ }^{33}$ laud the free-market efficiencies of counsel choice, ${ }^{34}$ and contend that counsel-choice doctrine is designed to shield the private defense bar from creeping socialism. ${ }^{35}$

The foregoing arguments illuminate important aspects of counsel choice. Yet they miss important justifications for, and potential benefits from, enforcing the right of counsel choice for poor people. Those justifications and benefits emerge when the analytical framework shifts from market to commons. That shift reveals both the democracy-enhancing potential of counsel choice and the importance of that potential given the antidemocratic impacts of the carceral state. ${ }^{36}$

This new analytical frame exposes the "no choice for the poor" stance as an antidemocratic concentration of judicial power that blocks grassroots constitutional lawmaking by poor people, who are also disproportionately people of color. ${ }^{37}$ Excluding poor people from the right to choose counsel creates an antidemocratic concentration of judicial power because judges typically have ultimate authority over the appointment of government-paid attorneys for people who cannot afford to hire a lawyer. ${ }^{38}$ Judicial appointment violates the first of the American Bar Association's Ten Principles of a Public Defense Delivery System by compromising the independence of the defense function. ${ }^{39}$ That independence

30. See Janet C. Hoeffel, Toward a More Robust Right to Counsel of Choice, 44 SAN DIEGO L. REV. 525, 527 (2007).

31. See Lefstein, supra note 13, at 916-20.

32. See, e.g., Hoeffel, supra note 30, at 541-45. Professor Hoeffel argues for the narrower right to continue a relationship with an appointed lawyer. $I d$.

33. See Wayne D. Holly, Rethinking the Sixth Amendment for the Indigent Criminal Defendant: Do Reimbursement Statutes Support Recognition of a Right to Counsel of Choice for the Indigent?, 64 BROOK. L. REV. 181, 182-83, 218-24 (1998).

34. See Stephen J. Schulhofer \& David D. Friedman, Rethinking Indigent Defense: Promoting Effective Representation Through Consumer Sovereignty and Freedom of Choice for All Criminal Defendants, 31 AM. CRIM. L. REV. 73, 109-10 (1993).

35. See John Rappaport, The Structural Function of the Sixth Amendment Right to Counsel of Choice, 2016 Sup. CT. REv. 117 (2017).

36. See Moore, supra note 1, at 1759-60.

37. Id. at 1707.

38. See, e.g., James M. Anderson \& Paul Heaton, How Much Difference Does the Lawyer Make? The Effect of Defense Counsel on Murder Case Outcomes, 122 YALE L.J. 154, 191-93 (2012) (discussing process in Philadelphia).

39. See Am. Bar Ass'n Standing Comm. on Legal Aid \& Indigent Defendants, Ten Principles of A Public Defense Delivery System 1-2 (2002), available at 

TO CHOOSE COUNSEL

is critical because it protects defenders from pressure to "back off from aggressively representing their clients" lest judges cut their fees or deny them future appointments. ${ }^{40}$ Perceptions of such pressure exacerbate "meet 'em and plead 'em" case processing that infects courtroom cultures and degrades expectations for defense performance. ${ }^{41}$

Including poor people in the right to choose counsel has democracyenhancing potential because it reallocates power over the defense function from judges to people who have the greatest need and incentive to mount a zealous defense. To be sure, free-market advocates of counsel choice cite the same shift in power as a way to better align defendants' liberty interests with defenders' pecuniary interests. ${ }^{42}$ However, that free-market focus misses the democracyenhancing potential inherent in that power shift. Including poor people in the right to choose counsel enhances democracy because it frees them to participate in constitutional lawmaking in ways that can strengthen the substantive meaning of a fundamental right.

This type of grassroots constitutionalism can occur for several reasons. First, the right to government-paid criminal defense counsel is an idiosyncratic federal constitutional mandate to distribute resources from haves to have-nots. ${ }^{43}$ That mandate derives not only from the Sixth Amendment but also from equal protection and due process guarantees. ${ }^{44}$ Thus, public defense comprises an exception to what Professor Julie Nice describes as the effective deconstitutionalization of poverty law. ${ }^{45}$ This distinctive characteristic opens a

http://www.americanbar.org/content/dam/aba/administrative/legal_aid_indigent_defendants/ls_s claid_def_tenprinciplesbooklet.authcheckdam.pdf [http://perma.cc/3CJQ-KTCW] [hereinafter TEN PRINCIPLES].

40. Jeff Blackburn \& Andrea Marsh, The New Performance Guidelines in Criminal Cases: A Step Forward for Texas Criminal Justice, 74 Tex. B.J. 616, 617 (2011), available at https://www.texasbar.com/AM/Template.cfm?Section=Texas_Bar_Journal\&Template=/CM/Co ntentDisplay.cfm\&ContentID=14703 [https:/perma.cc/JK7L-N5UD].

41. Steven B. Bright, The Past and Future of the Right to an Attorney for Poor People Accused of Crimes, in The Constitution and the Future of Criminal Justice in America 14 (John T. Parry \& L. Song Richardson eds., 2013) (describing “meet 'em and plead 'em” case processing); Nicole Gonzalez Van Cleve, Crook County: Racism and Injustice in AMERICA's LARGEST CRIMINAL COURT xiii-xiv, 3-6, 21-32 (2016) (describing degrading effects of "courtroom work group" culture); see also Jessi Stone, State tries to curb indigent defense expenses, Sмоку Mountain News (July 5, 2017), http://www.smokymountainnews. com/news/item/20283-state-tries-to-curb-indigent-defense-expenses [https://perma.cc/5HX5-PEJN] (describing cost-cutting pressures in local jurisdiction).

42. See, e.g., Schulhofer, supra note 28, at 539-40.

43. See Janet Moore, G Forces: Gideon v. Wainwright and Matthew Adler's Move Beyond Cost-Benefit Analysis, 11 Seattle J. Soc. J. 1025, 1051-58 (2013).

44. See Participatory Defense, supra note 26, at 1291-96.

45. Julie A. Nice, No Scrutiny Whatsoever: Deconstitutionalization of Poverty Law, Dual Rules of Law, \& Dialogic Default, 35 Fordham URB. L.J. 629, 629-38 (2008). 
window of opportunity for engagement with constitutional law, and with its implications for resource distribution, by the majority of criminal defendants - that is, by people who need public defense representation.

That window of opportunity opens wider thanks to the Supreme Court's substantive definition of "assistance of counsel." Under Strickland v. Washington, the right to counsel requires lawyers to act reasonably in light of prevailing attorney performance standards ${ }^{46}$ In other words, the substantive meaning of the Sixth Amendment right to counsel turns on real-world practices and the resources available to support high-quality attorney performance. ${ }^{47}$

This window of opportunity matters because attorney performance standards change over time. Some changes involve seismic shifts in the scope of attorney duties and corresponding resource needs. Examples include Argersinger $v$. Hamlin, which extended the right to appointed counsel from felonies to misdemeanors involving incarceration. ${ }^{48}$ Another example is Padilla v. Kentucky, which imposed a new constitutional requirement that defense counsel provide pre-plea information on the deportation consequences of a conviction. ${ }^{49}$

Other changes in constitutional attorney performance benchmarks are more gradual and iterative. For example, Strickland v. Washington established that capital defense lawyers must investigate evidence that can mitigate a sentence from death to life imprisonment. ${ }^{50}$ Years later, training and performance standards had shifted the focus of capital defense practice from seeking acquittals to preventing execution. $^{51}$ In the wake of that shift, the Court clarified in Wiggins $v$. Smith that lawyers have a constitutional duty to conduct an adequate preliminary investigation into mitigation evidence before they can make a reasonable decision to forego further investigation. ${ }^{52}$

These cases illustrate the dialogic process through which lawyers and courts shape the substantive meaning of the right to counsel..$^{53}$ Challenges to and improvements in existing performance standards raise the constitutional floor. Court rulings incorporate better practices into the definition of sound strategy.

46. 466 U.S. 668, 685 (1984) (quoting U.S. Const. amend. VI); id. at 687 (setting standard).

47. See Padilla v. Kentucky, 559 U.S. 356, 366-67 (2010). Evidence of prevailing performance standards include American Bar Association guidelines that cover the core defense functions of communication, investigation, and advocacy. See id. at 367; see also Marla Sandys \& Heather Pruss, Correlates of Satisfaction Among Clients of A Public Defender Agency, 14 Оніо Sт. J. CRIM. L. 431, 434 (2017).

48. 407 U.S. 25,30 (1972).

49. Padilla, 559 U.S. at 374-75; Chaidez v. United States, 568 U.S. 342, 353 (2013) (holding that Padilla created a "new rule" governing constitutionally-compliant attorney performance).

50. Strickland, 466 U.S. at 675-76, 691, 699.

51. David R. Dow, Bell v. Cone: The Fatal Consequences of Incomplete Failure, in DEATH Penalty Stories 395 (John H. Blume \& Jordan M. Steiker eds., 2009).

52. 539 U.S. 510 (2003).

53. Cf. Susan S. Silbey, After Legal Consciousness, 1 AnN. Rev. L. \& Soc. ScI. 323, 338 (2005). 
Those rulings inspire additional training to promote compliance. ${ }^{54}$

Including poor people in the right of counsel choice frees them to participate in this process through a form of grassroots constitutional law formation that can increase pressure, incrementally and over time, to improve attorney performance standards. That pressure should grow as the majority of people who face criminal charges force more information about attorney performance out of public defense systems, ${ }^{55}$ use that information to choose their lawyers, and, as indicated by the activities of the participatory defense movement, press for the additional resources needed for overworked, underfunded public defense systems to improve the quality of defense representation. ${ }^{56}$

That pressure would grow more quickly if counsel choice were made meaningful by, for example, providing information on standards that require lawyers to communicate, investigate, and advocate. ${ }^{57}$ An example of a simple trifold "know your rights" wallet card is below: ${ }^{58}$

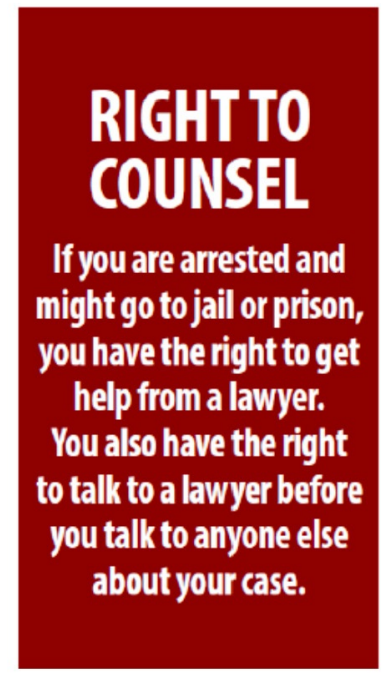

\section{YOUR LAWYER SHOULD: \\ LISTEN TO YOU about what \\ you want to happen in your case and who or what might help}

\section{TALK TO YOU about what is} happening in your case and how you can get in touch

KNOW THE LAW and be able to tell you why it matters in your case

LOOK FOR INFORMATION that can help you, including information police and prosecutors miqht have

HELP YOU get the best possible
result in your case by:
- Trying to get you released
if you are in jail before trial
- Trying to keep illegal
evidence out of court
- Preparing for trial
- Arguing for the best plea
and sentence possible
YOU CAN ASK YOUR LAWYER
TO DO THESE THINGS
FOR YOU OR
TO EXPLAIN WHY
THEY ARE NOT BEING DONE

54. See Jenny Roberts, Why Misdemeanors Matter: Defining Effective Advocacy in the Lower Criminal Courts, 45 U.C. DAvis L. REv. 277, 316-21 (2011).

55. Moore, supra note 1, at 1760-62.

56. See Participatory Defense, supra note 26. On the need for resource parity between defense and prosecution functions, see TEN PRINCIPLES, supra note 39 and Ronald F. Wright, Parity of Resources for Defense Counsel and the Reach of Public Choice Theory, 90 Iowa L. Rev. 219, 263-68 (2004).

57. Participatory Defense, supra note 26, at 1309-10.

58. Id. at 1310 . 
Armed with that information, people who need public defense counsel would be better positioned to recognize and challenge substandard performance not only in their own cases but also system-wide. ${ }^{59}$ Because Strickland incorporates realworld performance standards into the substantive definition of the right to counsel, improving those performance standards should gradually strengthen the meaning of the right. This redefinition of constitutional meaning should become manifest in the lived experiences of people who need public defense lawyers, in any ex post imprimaturs that courts stamp on better in-the-trenches practices, and in responsive attorney training programs that spread those improved practices to new settings. ${ }^{60}$

By accounting for this dialogic process of constitutional law formation, the democracy-enhancement framework refocuses analysis of counsel choice from the autonomous individual who bargains for service in the free market and contributes to an invisible, efficiency-producing hand that rewards good lawyers and drives bad ones out of business. ${ }^{61}$ Viewing counsel choice from the perspective of democratic theory highlights opportunities for collective grassroots lawmaking that can check concentrated government power while strengthening the substantive meaning of a fundamental constitutional right. Thus reframed, the right of counsel choice can be much more than an anomalous constitutional right to shop - a right that is, by definition, reserved for those who can afford the price of market entry.

Thus, to extend Professor Steven Winter's analysis, including poor people in the right of counsel choice is one way to mine democracy - the power (kratos) of the masses (demos) - in search of the more elusive and normatively robust isonomy - equal participation in the generation and administration of law. ${ }^{62}$ Thus reframed, an inclusive right of counsel choice can provide what Professor Heather Gerken describes as "the democratic churn necessary for an ossified national system to move forward." ${ }^{63}$ Section I.B highlights the importance of such "democratic churn" in strengthening the right to counsel and in checking the scope, power, and antidemocratic tendencies of the carceral state.

\section{B. The Antidemocratic Impacts of the Carceral State}

The "democratic churn" that can result from including poor people in the Sixth Amendment right to choose counsel - thereby raising pressure to improve attorney performance standards and, over time, strengthening the meaning of a fundamental constitutional right - is one way to counter the growing size and

59. Id. at 1309-15.

60. See Silbey, supra note 53, at 338-39.

61. Schulhofer, supra note 28, at 532; on the invisible hand, see ADAm SMITH, AN INQUIRY into the Nature and Causes of The Wealth of Nations 34-35 (1776).

62. Steven L. Winter, 'Down Freedom 's Main Line,' 41 Neth. J. Legal Phil. 202, 214, 237 38 (2012).

63. Heather K. Gerken, The Supreme Court, 2009 Term: Foreword: Federalism All the Way Down, 124 HaRV. L. ReV. 4, 10 (2010). 

TO CHOOSE COUNSEL

power of the carceral state. The latter term denotes the sprawling, dynamic network of policies, institutions, personnel, and apparatuses through which federal, state, local, and tribal governments exercise power to police, prosecute, and punish. ${ }^{64}$ The most recent wave of carceral state scholarship describes how criminal legal policies impose disproportionate and disenfranchising impacts on poor people, who are, in turn, disproportionately people of color. ${ }^{65}$ Those antidemocratic impacts deepen a preexisting democracy deficit in which the same people have high contact with criminal legal systems but little voice in generating and administering the governing law in ways that can reduce the pervasive scope and influence of those systems. ${ }^{66}$

Space constraints prevent full discussion of the complex factors that contribute to the growth and resilience of the carceral state. One factor salient here is a pattern of policy choices driven by the principle of austerity, which promotes disinvestment of tax dollars from evidence-based, cost-effective approaches to building individual and collective capacities for isonomy, or equal self-governance. ${ }^{67}$ Results of such austerity-driven policies include recalcitrant

64. See, e.g., Marie Gottschalk, Caught: The Prison State and the Lockdown of American Politics (2015) (discussing the interlocking, resilient structures that compose the carceral state and render it resistant to reform); $c f$. Utah v. Strieff, 136 S. Ct. 2056, 2070-71 (2016) (Sotomayor, J., dissenting) (interpreting majority's construction of Fourth Amendment as "impl[ying] that you are not a citizen of a democracy but the subject of a carceral state, just waiting to be cataloged").

65. See Detaining Democracy? Criminal Justice and American Civic Life, 651 Ann. AM. ACAD. POl. \& Soc. SCI. 6-21 (Christopher Wildeman et al. eds., 2014) [hereinafter Det AInING Democracy]; Amy E. Lerman \& Vesla M. Weaver, Arresting Citizenship: The Democratic Consequences of American Crime Control 6-13 (2014); Nat'L Research Council, The GROWTH OF INCARCERATION IN THE UNITED STATES:EXPLORING CAUSES AND CONSEQUENCES 91103, 233-58, 303-13 (Jeremy Travis et al. eds., 2014) [hereinafter NRC REPORT] (discussing racially disparate impact of carceral systems, including creation of lower categories of citizenship and disenfranchisement); Loï Wacquant, Crafting the Neoliberal State: Workfare, Prisonfare, and Social Insecurity, 25 Soc. F. 197, 199-200, 205-06 (2010).

66. See Sharon Dolovich \& Alexandra Natapoff, Mapping the New Criminal Justice Thinking, in The New Criminal Justice Thinking 1, 14-16 (Sharon Dolovich \& Alexandra Natapoff eds., 2017); Albert W. Dzur et al., Punishment and Democratic Theory: Resources for a Better Penal Politics, in Democratic TheORY AND MASS InCARCERATION 1, 6-10 (Albert W. Dzur et al. eds., 2016) [hereinafter Democratic Theory]; JAMEs Forman, JR., Locking Up Our own: Crime and Punishment in Black America 9-13 (2017); Janet Moore, Democracy Enhancement in Criminal Law and Procedure, 2014 UTAH L. REv. 543, 548-49 (2014).

67. See, e.g., Matthew Albright, Another $\$ 30$ million axed from state budget: education, public health hit, [DEL.] News Journal (May 30, 2017, 6:59 PM), http://www.delawareonline. com/story/news/politics/2017/05/30/committee-starts-slashing/355522001/[https://perma.cc/9PVV842S] (describing state-level cuts to same program); Richard J. Gelles, What We Can Expect from the Trump Administration, Chronicle Soc. Change (Jan. 17, 2017), https://chronicleofsocialchange.org/opinion/can-expect-trump-administration/23896 
pockets of concentrated disadvantage involving poor health, schooling, employment opportunities, and family and neighborhood cohesion, which metastudies demonstrate are closely linked to involvement with criminal legal systems. ${ }^{68}$

A related set of policy choices responds to resulting social problems by doubling down on investments in surveillance and punishment. ${ }^{69}$ Taken together, these policy choices make poverty "sticky" by hindering socioeconomic mobility. ${ }^{70}$ They reduce civic engagement among affected populations. ${ }^{71}$ They contribute to the carceral state's resilience in the face of reform efforts. ${ }^{72}$ They deepen the pre-existing democracy deficit that impedes effective political participation by poor people and people of color. ${ }^{73}$

Professor James Forman, Jr. vividly describes how the intersectional impact of race and class perpetuates carceral policies, even in jurisdictions like

[https://perma.cc/AW8H-TP2B] (noting that repeal of the Affordable Care Act "would eliminate funding for the Nurse Family Partnership, an evidence-based and cost-effective program" that develops capacities for successful participation in society); see also SHARON MiHALIC ET AL., U.S. DeP'T OF Just., BluePrints FOR Violence PREVENTION 1-20 (2004), available at https://www.ncjrs.gov/pdffiles1/ojjdp/204274.pdf [https://perma.cc/YN96-LKTB] (delineating criteria for selecting effective programming); MARTha C. Nussbaum, CREATING CAPABILitiEs: The Human Development ApProach, at xi-ii, 18-25 (2013) (discussing capacity-enhancing opportunities); Anne C. Dailey, Developing Citizens, 91 IowA L. REv. 431, 433-34 (2006) (arguing for constitutional recognition that early caregiving is "essential . . to the development of those psychological capacities that are necessary to the maintenance and flourishing of our modern democratic polity"); James Forman, Jr., Racial Critiques of Mass Incarceration: Beyond the New Jim Crow, 87 N.Y.U. L. REv. 21, 52 \& nn.118-19 (2012) (arguing that "the state frequently squanders opportunities to intervene before adolescents become murderers") (emphasis added); James J. Heckman, Skill Formation and the Economics of Investing in Disadvantaged Children, 312 SCI. 1900, 1900-01 (2006) (arguing for evidence-based programming on skills acquisition as a priority for disadvantaged children).

68. See Travis C. Pratt \& Francis T. Cullen, Assessing Macro-Level Predictors and Theories of Crime: A Meta-Analysis, 32 CRIME \& JUST. 373, 378-79 (2005) (citing "indicators of "concentrated disadvantage"" such as poverty and family disruption as among "the strongest and most stable macro-level predictors of crime”); Robert J. Sampson \& Lydia Bean, Cultural Mechanisms and Killing Fields: A Revised Theory of Community-Level Racial Inequality, in THE MANY COLORS OF CRIME 8, 11 (Ruth D. Peterson et al. eds., 2006) ("It is unambiguously the case in meta-analysis[] . . . that concentrated neighborhood disadvantage is the largest and most consistent predictor of violence across studies.").

69. See GotTschalk, supra note 64, at 10-14, 25-26; Wacquant, supra note 65, at 206-10.

70. Paul L. Caron \& James R. Repetti, Occupy the Tax Code: Using the Estate Tax to Reduce Inequality and Spur Economic Growth, 40 PEPP. L. REV. 1255, 1271 (2013).

71. See supra notes 65-66 and accompanying text.

72. Caron \& Repetti, supra note 70, at 353; see generally GotTSCHALK, supra note 64.

73. Loïc Wacquant, Class, Race and Hyperincarceration in Revanchist America, 139 DAEDALus 74, 78-79 (2010); see also NRC REPORT, supra note 65, at 314-17. 
Washington, D.C. where African Americans are in the political majority. ${ }^{74} \mathrm{~A}$ central problem is the inability to implement redistributive policies that correlate with sustainable crime prevention. ${ }^{75}$ Instead, disinvestment in human capacitybuilding accompanies tough-on-crime policies: ${ }^{76}$

African Americans wanted more law enforcement, but they didn't want only law enforcement. Many adopted what we might think of as an allof-the-above strategy . . . they called for jobs, schools, and housing — what many termed "a Marshall Plan for urban America." But because African Americans are a minority nationally, they needed help to win national action against poverty, joblessness, segregation, and other root causes of crime. The help never arrived. ${ }^{77}$

As indicated by this brief summary of scholarship on the carceral state, the principle of austerity in public funding for the programs and institutions that are necessary for healthy human development is closely linked with an increased risk of crime and involvement with criminal legal systems. Conversely, the literature indicates that reducing crime and the footprint of the carceral state requires increased isonomy - the equal capacity for individual and communal selfgovernance, including among members of disadvantaged and highly-policed communities. It is this demonstrated need for increased self-governance that heightens the importance of opportunities for effective grassroots lawmaking by the low-income people who are disproportionally accused, convicted, and sentenced. ${ }^{78}$

As discussed in Section A, such potential for grassroots lawmaking is inherent in the inclusion of poor people in the right to choose criminal defense lawyers. An opportunity to evaluate this potential arose with what appears to be the nation's first experiment with counsel choice in the public defense context. Part II discusses that pilot study, including the libertarian theory and related commitment to austerity in government services that influenced project design, implementation, and results.

74. FORMAN, supra note 66, at 12-13.

75. Id.

76. Id.; see generally KATHERINE BECKETT \& StEVE HERBERT, BANISHED (2009); EliZABETH Hinton, From the War on Poverty to the War on Crime: The Making of Mass Incarceration in America (2016); LoḮ Wacquant, Punishing the Poor: The Neoliberal GOVERnMENT OF SOCIAL INSECURITy (2009).

77. FORMAN, supra note 66 , at 12.

78. For examples of relevant social movements, see, e.g., Participatory Defense, supra note 26; Maura Ewing, How Prisoners' Family Members Can Assist Overworked Public Defenders, ATLANTIC (July 5, 2017), https://www.theatlantic.com/politics/archive/2017/07/a-replacement-foroverworked-public-defenders/532476/ [https://perma.cc/K9HJ-3QGL]; Jocelyn Simonson, Copwatching, 104 CAL. L. REv. 391, 392 (2016); Michael Leo Owens, Ex-Felons' OrganizationBased Political Work for Carceral Reforms, in DETAINING DEMOCRACY, supra note 65, at 256-59. 


\section{COUNSEL CHOICE, LIBERTARIAN THEORY, AND THE AUSTERITY PRINCIPLE}

This Part contrasts Part I's framing of counsel choice as an exercise in democratic theory with a description of how libertarian theory shaped the inception, design, and implementation of the pilot study on counsel choice undertaken in the Comal County, Texas public defense system. Part II.A discusses the study's genesis. Part II.B discusses formation of the leadership team. Part II.C describes site selection.

\section{A. The Libertarian Origins of Counsel Choice in Texas}

The official report on the Comal County counsel choice pilot study summarizes the project history as follows: planning began in 2012; the research team was established in 2013; counsel choice was implemented for a year beginning in 2015; it was evaluated, was deemed a success, and is continuing. ${ }^{79}$ That summary raises questions about how and why counsel choice emerged as a priority on the public defense reform agenda in Texas. ${ }^{80}$ Investigating those questions reveals a more detailed project history than the official report provides. The same investigation offers richer insight into the theory and principles that contributed to the project's genesis, design, implementation, and results.

The project's guiding principles were drawn from two primary theories. The first was a form of libertarian theory promoted by individuals and institutions dedicated to methodological individualism, private enterprise, small government, low taxes, and austerity in budgeting for public services. ${ }^{81}$ The second major influence was a strand of procedural justice theory that tends to focus on strategies for increasing perceptions of fairness and compliance with system demands instead of strategies for addressing the substantive and distributive fairness of system inputs and outcomes, underlying asymmetries in access to power and resources, and the informational and community organizing deficits that tamp down resistance to such asymmetries. ${ }^{82}$

The relationship between these two theoretical foundations for the Comal County pilot study invites further analysis. For example, scholars might fruitfully investigate whether and how libertarian and procedural justice theories interact

79. NugEnT-BorAKove ET AL., supra note 8, at 1, 9, 42.

80. See Janet Moore \& Andrew L.B. Davies, Knowing Defense, 14 OHIо ST. J. CRIM. L. 345, 346 (2017) (theorizing and evaluating formation of research agendas).

81. See Peter Vallentyne \& Bas van der Vossen, Libertarianism, STANFORD ENCYCLOPEDIA of Philosophy Archive (Edward N. Zalta ed., Fall 2014), available at https://plato.stanford.edu/ archives/fall2014/entries/libertarianism/ [https://perma.cc/E8BU-ERTM].

82. See, e.g., Anthony Bottoms \& Justice Tankebe, Beyond Procedural Justice: A Dialogic Approach to Legitimacy in Criminal Justice, 102 J. CRIM. L. \& CRIMINOLOGY 119 (2012); Devon Johnson et al., Public Perceptions of the Legitimacy of the Law and Legal Authorities: Evidence from the Caribbean, 48 LAw \& Soc'Y Rev. 947 (2014); Robert J. MacCoun, Voice, Control, and Belonging: The Double-Edged Sword of Procedural Fairness, 1 ANN. REV. L. \& Soc. SCI. 171, 188-93 (2005); Justice Tankebe, Viewing Things Differently: The Dimensions of Public Perceptions of Police Legitimacy, 51 CRIMINology 103 (2013). 

TO CHOOSE COUNSEL

in shaping research agendas, projects, and policy formation involving criminal legal systems. This Article begins to explore those questions by identifying the role of libertarian theory and, more specifically, a commitment to the principle of austerity in government spending, on the Comal County counsel choice project. As discussed below, those theoretical commitments sharply constrained the measure and meaning of counsel choice that was offered, the data generated, and the ability of those data to support generalizable conclusions.

This more detailed history of the Comal County counsel choice pilot study emerges from government documents and other communications, including a December 2014 Federalist Society podcast. ${ }^{83}$ Although the organization is wellknown in legal circles,${ }^{84}$ it is worth noting a few key aspects of the Society's selfdescription.

The Federalist Society is "a conservative and libertarian intellectual network" that opposes the perceived dominance in law and legal education of an "orthodox liberal ideology which advocates a centralized and uniform society." ${ }^{85}$ Core principles include limiting the respective roles of the state and the judiciary to preserving freedom and saying "what the law is, not what it should be." Promoting these principles requires training people, particularly people in the legal field, to prioritize "individual liberty, traditional values, and the rule of law." $" 87$

It was presumably in furtherance of this mission that the Federalist Society sponsored the podcast on the Texas counsel choice project. That podcast traces the project's genesis to an email sent in the fall of $2010{ }^{88}$ The email was from Marc Levin, who directs the Right on Crime project at the Texas Public Policy Foundation (TPPF) ${ }^{89}$ TPPF's mission resonates with that of the Federalist Society, in that TPPF seeks to "promote and defend liberty, personal

83. Public Defenders and Client Choice, Federalist SoC'y (Dec. 19, 2014), http://www.fedsoc.org/multimedia/detail/public-defenders-and-client-choice-podcast [https://perma.cc/KGA6LLUD] [hereinafter Podcast].

84. See, e.g., Amanda Hollis-Brusky, Ideas With Consequences: The Federalist Society And the Conservative Counterrevolution 2-4 (2015); Jeffrey Toobin, The Conservative Pipeline to the Supreme Court, NEw YORKER (Apr. 17, 2017), http://www.newyorker. com/magazine/2017/04/17/the-conservative-pipeline-to-the-supreme-court [https://perma.cc/DRF5NQK9]. The author has served as a Faculty Advisor for a local student chapter of the American Constitution Society, which emerged in response to the Federalist Society. See Jonathan H. Adler, FedSoc v. ACS, Volokh Conspiracy (June 29, 2010, 7:09 PM), http://volokh.com/ 2010/06/19/fedsoc-v-acs/ [https://perma.cc/2AGZ-6MXP].

85. About Us, FEDERALIST SoC'Y, https://fedsoc.org/about-us [https://perma.cc/WM4NKLTC] (last visited Oct. 29, 2017).

86. Id.

87. Id.

88. Podcast, supra note 83, at 16:23-16:44.

89. Id.; see also Marc Levin, Tex. Pub. PoliCy Found., https://www.texaspolicy. com/experts/detail/marc-levin [https://perma.cc/GB3X-A4VH] (last visited Feb. 12, 2018). 
responsibility, and free enterprise in Texas and the nation by educating and affecting policymakers . . . with academically sound research and outreach." TPPF is part of the State Policy Network, ${ }^{91}$ which was founded at the urging of Ronald Reagan to strengthen the nationwide development, coordination, and impact of "market-oriented, state-focused think tanks."

In terms of funding and efficacy, TPPF has been described as "the big kid on the block" among think tanks not only in its home state, where it is pivotal to "[b]uilding the foundation of Texas conservatism," but nationally as well. ${ }^{93}$ Examples include TPPF's Right on Crime project, whose "raison d'etre is to 'fight crime, support victims, and protect taxpayers." "94 Like TPPF itself, the Right on Crime project is an important part of a larger national campaign. ${ }^{95}$ TPPF's Marc Levin is on the leadership team for the national Right on Crime initiative, where he serves as Policy Director. ${ }^{96}$

The email that Mr. Levin sent in the fall of 2010 forwarded a policy paper from the Cato Institute. ${ }^{97}$ Cato shares TPPF's mission of promoting "individual liberty, limited government, [and] free markets." 98 In the Cato policy paper, Professors Stephen Schulhofer and David Friedman updated a 1993 law review article in which they opposed what they described as "the monopoly position" of public defense offices and sought to "privatize" public defense through the use of vouchers. ${ }^{99}$ Their Cato paper maintained the same pro-voucher position as the

90. About, Tex. Pub. Policy Found., https://www.texaspolicy.com/about/ [https://perma.cc/5X7G-CPCP] (last visited Oct. 29, 2017).

91. Directory, StATE POLICY NeTWORK, https://spn.org/directory/ [https://perma.cc/ZKH5V2EC] (last visited Oct. 29, 2017).

92. State Solutions National Impact, STATE Policy NeTwork, https://spn.org/ [https://perma.cc/QD5E-SX3E] (last visited Dec. 31, 2017).

93. Neena Satija, Building the Foundation of Texas Conservatism, TEX. TRIB. (Jan. 7, 2015, 6:00 AM), https://www.texastribune.org/2015/01/07/tppf-moving-legislature-convenes/ [https://perma.cc/8NE3-MSF7]; see also Stephen Moore, Conservative State Think Tanks: The Left tries to shut them down because they're winning, NAT'L REVIEW DigitAL (Apr. 7, 2014), https://www.nationalreview.com/nrd/articles/373782/conservative-state-think-tanks [https://perma.cc/6SMV-BNU8] (describing network's efficacy).

94. Michael Haugen, Right on Crime Seeks to Improve The Criminal Justice System in Its Entirety, TeX. Pub. PoL'Y. Found. (May 20, 2015), https://www.texaspolicy.com/blog/detail/righton-crime-seeks-to-improve-the-criminal-justice-system-in-its-entirety [https://perma.cc/VH452UCA].

95. Texas, RIGHT ON CRIME, http://rightoncrime.com/category/state-initiatives/texas/ [https://perma.cc/MN35-RSLP] (last visited Oct. 29, 2017).

96. About Right on Crime, The Right on Crime Team, Right ON CRIME, http://rightoncrime.com/about/ [https://perma.cc/PX6H-KT4F] (last visited Oct. 29, 2017).

97. Podcast, supra note 83, at 16:23-16:44.

98. Cato's Mission, CATO InSt., https://www.cato.org/mission [https://perma.cc/C7A8YEYH] (last visited Nov. 1, 2017). Cato's mission statement also expresses dedication to "principles of . . p peace." Id.

99. See Stephen J. Schulhofer \& David D. Friedman, Cato Inst., Reforming Indigent 

TO CHOOSE COUNSEL

1993 article, but offered more detailed arguments to support the underlying thesis that government-paid criminal defense lawyers have intractable conflicts of interest because they are beholden to the same entity that supports the prosecution. ${ }^{100}$

Mr. Levin sent the Cato policy paper to Jim Bethke, the Executive Director of what was then the Texas Indigent Defense Task Force. ${ }^{101}$ The Texas legislature created the Task Force in 2001 to address concerns about the efficiency and quality of public defense in Texas. ${ }^{102}$ Representative denunciations from that time period include the blunt assessment of a state Bar committee that public defense in Texas was "a national embarrassment." 103

The state legislature responded to the public criticism by passing the Fair Defense Act. ${ }^{104}$ The Act empowered the Task Force to promote data-based analysis of strategies for improving public defense, including through the provision of grants to incentivize and support local innovation. ${ }^{105} \mathrm{~A}$ decade later, the legislature transformed the Task Force into the Texas Indigent Defense Commission (TIDC). ${ }^{106}$ That change did not affect the agency's purpose or activities, however, and leadership remained stable with Mr. Bethke at the helm. ${ }^{107}$

Due to Mr. Bethke's demonstrated leadership on indigent defense reform at both the state and national level, by the time he received the TPFF email he was also serving on the American Bar Association's Indigent Defense Advisory Group (IDAG). The IDAG chair was another "thought leader" on counsel choice, Dean Norman Lefstein. ${ }^{108}$ Mr. Bethke discussed the Cato policy paper with Dean Lefstein and learned about the Dean's own research on counsel choice in

Defense: How Free Market Principles Can Help to Fix a Broken System, No. 666 (Sept. 1, 2010) [hereinafter POLICY PAPER]; Schulhofer \& Friedman, supra note 34, at 75-76.

100. POLICY PAPER, supra note 99, at 1 .

101. Podcast, supra note 83, at 16:23-17:06.

102. Texas Indigent Def. Comm'n, Fair Defense Law: A Primer for Texas County OfFICIALS 1 (2017), available at http://www.tidc.texas.gov/media/52836/2017_primer-for-countyofficials_final3.pdf [https://perma.cc/423T-FRJM].

103. Allan K. Butcher \& Michael K. Moore, Muting Gideon's Trumpet: The Crisis IN INDIGent CRIMINAL DefEnSE IN TEXAS 23 (2000), available at http://docplayer.net/980366Muting-gideon-s-trumpet-the-crisis-in-indigent-criminal-defense-in-texas.html [https://perma.cc/FQG6-EHZJ].

104. S.B. 7, 77th Leg. (Tex. 2001).

105. James D. Bethke \& Morgan Shell, Public Defense Innovation in Texas, 51 Ind. L. REv. 111, 112-13 (2018).

106. See generally, The State of Tex., Indigent Defense: An Issue Brief From Legislative Budget BoARd StAFF (July 2016), available at http:/www.lbb.state.tx.us/ Documents/Publications/Issue_Briefs/3113_Criminal_Defense_Legal_Services_Indigent.pdf [https:/perma.cc/V6EJ-CDZ3] [hereinafter Issue BRIEF].

107. Bethke \& Shell, supra note 105, at 112-13.

108. Podcast, supra note 83, at 17:39-18:20; see Lefstein, supra note 13, at 840 n.24. 
England, Scotland, and other common law countries. The discussion left $\mathrm{Mr}$. Bethke "intrigued" with the counsel choice concept. ${ }^{109}$ With his encouragement, the Task Force began planning to collaborate with TPFF and Cato to implement a public defense voucher program in Texas. ${ }^{110}$

That planning paid off. By January 2014, editorials in the New York Times and Washington Post were lauding the public defense voucher experiment in Texas. ${ }^{111}$ By December of the same year, the Texas pilot study was poised for launch as the Federalist Society podcast expressly analogized the program to "the school voucher concept" in aiming to "replicate, so far as possible, a free market for defense services." 112 With Cato's Tim Lynch moderating the podcast, Professor Schulhofer argued that vouchers would reinstate "consumer sovereignty" and "obliterate conflicts of interests" in public defense. ${ }^{113} \mathrm{He}$ also contended that vouchers would free defendants from overextended public defenders and "fly-by-night" assigned counsel, while shrinking excessive caseloads by bringing new lawyers into the market to compete for cases. ${ }^{114}$

To objections that choice means little without the additional resources necessary for quality representation, Professor Schulhofer offered two responses. First, he argued that counsel choice would lead to more funding for public defense offices. ${ }^{115}$ This would occur, he contended, because increased attorney effort would raise costs. ${ }^{116}$ That development would in turn lead funders to discover that public defense offices are more efficient than private counsel and to shift resources accordingly. ${ }^{117}$

Professor Schulhofer also argued against increased funding on the basis that, in the absence of counsel choice, more money would only aggravate defender dependence on government and the resulting conflicts of interest as lawyers try to please appointing judges and judges appoint lawyers who offer minimal resistance. ${ }^{118}$ Aspects of those arguments were echoed by at least one judge in Comal County, who doubted that "throwing money" at broken public defense systems would fix them. ${ }^{119}$

109. Podcast, supra note 83, at 3:48-4:00; Lefstein, supra note 13, at 861 .

110. Podcast, supra note 83, at 17:07-17:38.

111. See Adam Liptak, Need-Blind Justice, N.Y. Times (Jan. 4, 2014), http://www.nytimes. com/2014/01/05/Sunday-review/need-blind-justice.html?_r=0 [https://perma.cc/LRQ4-KZDW]; see also Radley Balko, In Texas, a novel idea to address the public defender crisis, WASH. PosT (Jan. 28, 2014), https://www.washingtonpost.com/news/opinions/wp/2014/01/28/in-texas-a-novelidea-to-address-the-public-defender-crisis/ [https://perma.cc/4DGC-A9C4].

112. Podcast, supra note 83, at 2:37-3:24 (including additional website information); see also Schulhofer, supra note 28 , at 551.

113. Podcast, supra note 83, at 11:10-11:20.

114. Id. at 12:20-12:58; see also Schulhofer, supra note 28, at 551-52.

115. Podcast, supra note 83 , at 41:13-42:49.

116. $I d$.

117. Id.; see also Schulhofer, supra note 28, at 537-39.

118. Podcast, supra note 83, at 39:06-40:20; see also Schulhofer, supra note 28, at 539-40.

119. Indigent Defense Idea to Get First Test in US, CBS DFW (Dec. 28, 2014, 4:57 PM), 

TO CHOOSE COUNSEL

The foregoing project history traces the influence on the Texas counsel choice experiment of libertarian theory and related commitments to methodological individualism, free markets, private enterprise, small government, low taxes, and austerity in budgeting for public services. The success of project proponents in putting counsel choice on the radar is noteworthy given the obstacles that they faced. Those obstacles included the negative state of the law and perceptions of the law, ${ }^{120}$ the relative paucity of scholarship on the subject, ${ }^{121}$ and attitudes in the public defense bar ranging from disinterest ${ }^{122}$ to skepticism ${ }^{123}$ and overt hostility. ${ }^{124}$

Those obstacles to prioritizing the counsel choice project could only have been exacerbated by the serious resource constraints that face public defense providers in Texas. With Comal County as the salient example, attorneys who resolve a felony case with a guilty plea face a $\$ 650$ fee cap absent extraordinary circumstances. ${ }^{125}$ The state's own workload study found that attorneys should invest between sixteen and thirty hours in a felony case before entering a guilty plea. ${ }^{126}$ Thus, based on that workload study and absent exceptional circumstances, attorneys doing what they should do before entering a guilty plea in a Comal County felony case receive a maximum of $\$ 22$ to $\$ 40$ per hour.

Those rates are among the lowest in the nation. ${ }^{127}$ They are from five to ten times lower than fees charged on the local private market. ${ }^{128}$ They could not cover

http://dfw.cbslocal.com/2014/12/28/indigent-defense-idea-to-get-first-test-in-us/ [https://perma.cc/8GEA-KBTM] (quoting Comal County Judge Dib Waldrip).

120. See Moore, supra note 1, at 1706-07.

121. Id. at 1707.

122. Moore \& Davies, supra note 80 , at 350-52.

123. See, e.g., Ernie Lewis, You want fries with that?, NAT'L Ass'N FOR PUB. Def. (Feb. 6, 2014), http://96.5.71.27/?q=node/216 [https://perma.cc/6EMJ-NPWU].

124. See, e.g., John Stuart, ARRRGH! 6 Rants about Vouchers, NAT. AsS'N FOR PUB. Def. (Feb. 13, 2014), http://www-old.publicdefenders.us/?q=node/232 [https://perma.cc/46SK-HXBF].

125. Dist. Cts. of Comal, Caldwell \& Hays Counties of TeX., Order Adopting Local

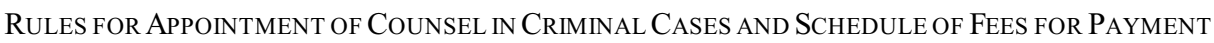
OF COMPEnSATION to Appointed Counsel (Oct. 18, 2017), available at http://tidc.tamu.edu/ IDPlanDocuments/Comal/Comal\%20District\%20Court\%20Attorney\%20Fee\%20Schedule.pdf [https://perma.cc/M2LE-9NMK].

126. Dottie Carmichael et al., Tex. A \& M Univ. Pub. Policy Research Inst., GuIDELINES FOR INDIGENT DEFENSE CASELOADS 28 fig. 8-1, app. I-1 (2015), http://www.tidc.texas. gov/media/31818/150122_weightedcl_final.pdf [https://perma.cc/QY93-UNFJ].

127. John P. Gross, Nat'L Ass'n Crim. Def. Lawyers, Gideon at 50: A Three-Part Examination of Indigent Defense in America: Part I: Rationing Justice: The UndERFunding OF ASSIGNED COUnSEl Systems 12-14 (2013), available at https://www.nacdl. org/gideonat 50/Gideon\%20at\%2050\%20-\%20Part\%201\%20Rationing\%20Justice.pdf [https://perma.cc/U2MF-A3HL].

128. NugENT-BoraKove ET AL., supra note 8, at 21. 
"the basic costs of keeping a law practice open in Mississippi in 1990."129 They raise serious questions about whether lawyers can respond to counsel choice by squeezing a bigger bang from a badly emaciated buck.

Nor does the "exceptional circumstances" escape hatch appear to offer much relief. With one exception, which encompassed the year of the pilot study, available fee data for felony cases in Comal County tend to support Professor John Gross's assessment that a so-called "soft cap" on fees acts as an anchor and discourages significant increases in compensation for attorney performance. ${ }^{130}$ The data in Table 1 are drawn from TIDC's Smart Defense data portal. ${ }^{131}$

Table 1

Assigned Counsel Felony Fees Paid

Comal County, Texas FY 2012-2016

\begin{tabular}{|c|c|c|c|c|}
\hline Year & Cases Paid & Total Fees & $\begin{array}{c}\text { Average } \\
\text { Fee/Case }\end{array}$ & $\begin{array}{c}\text { Average } \\
\text { Fee Cap } \\
\text { Variance } \\
(\%)\end{array}$ \\
\hline 2012 & 481 & $\$ 355,801$ & $\$ 739.71$ & 14 \\
\hline 2013 & 523 & $\$ 350,914$ & $\$ 670.96$ & 3 \\
\hline 2014 & 475 & $\$ 355,048$ & $\$ 747.47$ & 15 \\
\hline 2015 & 446 & $\$ 451,443$ & $\$ 1,131.53$ & 75 \\
\hline 2016 & 500 & $\$ 378,489$ & $\$ 756.98$ & 16 \\
\hline Average & 485 & $\$ 378,339$ & $\$ 809.33$ & 25 \\
\hline
\end{tabular}

The data indicate that although case numbers and distribution across charge levels remained fairly constant, average fees spiked $75 \%$ above the fee-capped baseline in FY 2015 before reverting toward that baseline. ${ }^{132}$ The official report on the counsel choice pilot study cites "anecdotal information" to suggest that the FY 2015 spike was due to one "particularly high profile, complex, and prolonged" felony case. ${ }^{133}$

However, these data include four capitally-charged cases - two in 2016 and

129. Sixth Amendment Ctr., Justice Shortchanged: Assigned Counsel Compensation IN WisCONSIN 2 (2015), available at http://sixthamendment.org/wp-content/uploads/ 2015/04/6AC_wijusticeshortchanged_2015.pdf [http://perma.cc/5TJ5-BQ8W].

130. GROss, supra note 127 , at 14.

131. See Indigent Defense Data for Texas: County Dashboard: Comal: View Attorney Caseload Report: 2014-2016, TeX. Indigent DeF. Comm'N, http://tidc.tamu.edu/public.net/ Reports/AttorneyCaseLoad.aspx?cid=46 [https://perma.cc/X8HB-ARDR] (last visited Nov. 2, 2017) [hereinafter Caseload Report]; Indigent Defense Data for Texas: County Dashboard: Comal: View County Datasheet, Tex. Indigent DeF. Comm'N, http:/tidc.tamu.edu/public.net/ Reports/DataSheet.aspx?cid=46 [https://perma.cc/7VJU-6EXL] (last visited Nov. 2, 2017).

132. See Nugent-Borakove ET AL., supra note 8, at 42 .

133. Id. 

TO CHOOSE COUNSEL

one each in 2015 and $2014 .{ }^{134}$ One would reasonably expect cases involving the death penalty to be "particularly high profile, complex, and prolonged." As far back as the 1990s, the average cost of investigation and litigating a federal death penalty case to a guilty plea was nearly $\$ 200,000 .^{135}$

The available data indicate that nothing remotely approaching that level of investment occurs in Comal County. Nevertheless, if the FY 2015 funding spike truly resulted from a single case, four capitally charged cases should have leveled out the spike by squeezing more resources out of the system over time. The absence of such leveling seems to reinforce two conclusions. First, the "extraordinary circumstances" escape hatch from the Comal County fee cap is an inadequate solution to the systematic underfunding of public defense. Second, the same lack of resources limits attorney capacity to respond to counsel choice by increasing the time and effort invested in fulfilling the core duties to communicate, investigate, and advocate.

Similar resource constraints at the state level may have led TIDC initially to seek federal taxpayer support for the counsel choice experiment through a grant from the U.S. Department of Justice Bureau of Justice Assistance. ${ }^{136}$ When that grant application was unsuccessful, TIDC allocated $\$ 200,000$ of its own funds for project "design, implementation and impact assessment" and for an accompanying program to train and mentor participating attorneys. ${ }^{137}$ It bears noting that the overwhelming majority of TIDC's budget comprises court costs, fees, and surety bonds paid by people convicted of crimes in Texas courts. ${ }^{138}$ Those fees are on top of the millions of dollars that counties recoup from defendants for public defense representation. ${ }^{139}$ In 2015, for example, the year

134. Caseload Report, supra note 131.

135. Hon. James R. Spencer et al., Jud. Conf. of the U.S., Subcomm. on Fed. Death Penalty Cases, Federal Death Penalty Cases: Recommendations Concerning the Cost AND QuALITY OF DEFENSE REPRESENTATION 3 (1998), available at https://www.americanbar.org/ content/dam/aba/uncategorized/Death_Penalty_Representation/Standards/National/federal_judi cial_conference_recommendations.authcheckdam.pdf [https://perma.cc/C44Y-6KBU].

136. Tex. Indigent Def. Comm'n, Rep. from the Texas Indigent Defense Commission 2 (Nov. 9, 2012), available at http://www.txcourts.gov/media/558056/TIDC-TJC-Report-11-912.pdf [https://perma.cc/RP97-AUQK].

137. Id.

138. Jim Bethke, Texas Indigent Defense Commission Asks State to Close the Indigent Defense Funding Gap, TEX. Ass'N OF CounTIES (Dec. 20, 2012), http://www.county.org/magazine/ departments/messageforyou/Pages/December\%202012/Texas-Indigent-Defense-Commission-AsksState-to-Close-the-Indigent-Defense-Funding-Gap.aspx [https://perma.cc/7Y28-4Z92]; see also Tex. Indigent Defense Comm’n, Rep. on State of Indigent Defense 18 (2016), available at http://tidc.texas.gov/media/47952/20160426CJDBriefing.pdf [https://perma.cc/7H93-W5HG] [hereinafter TIDC 2016 REPORT] (documenting funding sources).

139. Tex. Indigent Def. Comm'n, Rep. From the Texas Indigent Defense Commission FOr February 20, 2015 TeXas Judicial Council MeEting 3, available at (2015), http://www. txcourts.gov/media/857010/TIDC-TJC-Report-022014_Final.pdf [https://perma.cc/KYY2-DTAH]. 
that the counsel choice project was implemented, defendants reimbursed Comal County for just over $10 \%$ of total public defense expenditures. ${ }^{140}$

Despite the size of the defendant's financial stake in a demonstrably underresourced public defense system, none of the \$200,000 in TIDC funding for the Comal County counsel choice project was allocated to increase support for direct representation by participating attorneys. Based on the state's workload study, areas of particular need include attorney-client communication, case investigation, independent forensic and mental health experts, and mitigation assistance from social workers or others who are trained for that work. ${ }^{141}$ Instead of offering additional resources to meet these needs in response to the increased pressure that counsel choice was expected to generate, key project proponents promised to implement counsel choice with no additional system costs beyond the initial research and training investments. ${ }^{142}$ They also anticipated that counsel choice would cut costs by moving cases more quickly, increasing defendant compliance by improving perceptions of fairness, and reducing post-conviction challenges. ${ }^{143}$

Thus, principles of austerity and cost containment had a strong influence on project conception, design, and, as discussed below, on implementation and results. To be sure, pressures for the efficient use of taxpayer dollars are inevitable and justifiable. Nevertheless, this fuller accounting of the theory that shaped the counsel choice project underscores preexisting questions, some of which are reflected in the study report, about whether and how counsel choice can be meaningful under conditions of serious resource constraint. ${ }^{144}$

At the same time, TIDC's decision to allocate scarce resources to the counsel choice project amid sharply competing demands demonstrates that the project was a priority for the agency. The following subsection provides additional detail on those competing demands and how they shaped the context within which the project's leadership team came together.

140. Indigent Defense Data for Texas: Comal Cnty.: 2015: Indigent Defense Expenditure Report Results: Total Indigent Defense Costs and Cases \& Reimbursements from Defendants, TEX. Indigent Def. COMM'N, http://tidc.tamu.edu/public.net/Reports/ExpenditureReportResults.aspx [https://perma.cc/2T47-EVTZ] (last visited Oct. 29, 2017) [hereinafter Comal County 2015 Expenditure Report] (showing recoupment of $\$ 82,871$ toward $\$ 800,026$ in total spending).

141. See CARMichael ET AL., supra note 126 , at 20 figs. $6.1 \mathrm{~b} \& 6.1 \mathrm{c}$.

142. State of Tex., Cnty. of Comal, Term Minutes of the Comal County COMmissioners Court MeEting 6-10 (May 17, 2012), available at http://www.co.comal.tx.us/ CCT-Minutes/2012/20120517.pdf [https://perma.cc/N25Y-MM96] [hereinafter TERM MinUTES 2012] (noting that participating in counsel choice pilot study would not create new costs for the County).

143. Id.

144. Moore, supra note 1, at 1707-09; cf. TERM Minutes 2012, supra note 142, at 7-10; Nugent-BoraKove ET AL., supra note 8, at 22 ("One of the key arguments for implementing Client Choice is to introduce free market forces that encourage competition leading to improved quality. However, the level of competition cannot be separated from the level of compensation.”). 

TO CHOOSE COUNSEL

\section{B. Forming the Leadership Team}

TIDC Executive Director Jim Bethke anchored the four-man team that led the planning of the Comal County counsel choice project. ${ }^{145}$ Professor Schulhofer and Dean Lefstein were also on the planning team, as was Edwin Colfax, TIDC's Grant Program Manager. ${ }^{146}$ In their roles with TIDC, Mr. Bethke and Mr. Colfax have significantly advanced the agency's mission of using research and data to evaluate and improve public defense in Texas. ${ }^{147}$ TIDC's support for impact assessment as part of the counsel choice pilot project is consistent with that commitment.

Indeed, it is difficult to overstate TIDC's contributions to data-driven analysis of public defense. Leading examples of TIDC-led research include the agency's partnership with Professor Dottie Carmichael at Texas A\&M University's Public Policy Research Institute. Dr. Carmichael led the design and implementation of the statutorily mandated workload study that highlighted disparities between the existing need for public defense services and the resources available to meet that need. ${ }^{148}$ Also in partnership with Dr. Carmichael, and with support from a U.S. Department of Justice "Smart Defense" grant, TIDC is pioneering a web-based portal that offers what appears to be the nation's most advanced system for reporting essential performance indicators related to public defense. ${ }^{149}$

TIDC's contributions to data-driven analysis of public defense are noteworthy for a number of reasons. First, criminal legal systems in general, and public defense systems in particular, are notoriously data-poor. ${ }^{150}$ Second, empirical research on public defense is in its infancy compared to better-funded and more developed fields that focus on police and prisons. ${ }^{151}$ Indeed, the field of public defense research has only recently begun to coalesce into a community that can share ideas and scarce resources with the help of organizations such as

145. Nugent-BoraKove ET AL., supra note 8, at 1.

146. Id.

147. Bethke \& Shell, supra note 105; Jennifer E. Laurin, Data and Accountability in Indigent Defense, 14 OhIO St. J. CRIM L. 373, 381 (2017); see also Caseload Report, supra note 131; TeX. INDIGENT DEF. COMM'N, supra note 140.

148. CARMiChAEL ET AL., supra note 126, at app. I-1; see also Geoffrey T. Burkhart, How to Leverage Public Defense Workload Studies, 14 OHIO ST. J. CRIM. L. 403, 409-10 (2017).

149. See supra note 131 and accompanying text. For another pioneering model of data analytics in public defense, see The North Carolina Systems Evaluation Project, N.C. Off. OF Indigent Def. Servs., http://www.ncids.org/Systems Evaluation Project/SEP HomePage.html?c=Research and Reports, Systems Evaluation Project [https://perma.cc/G5ZPEU26] (last visited Nov. 3, 2017).

150. Laurin, supra note 147, at 381; see also Jennifer E. Laurin, Gideon by the Numbers: The Emergence of Evidence-Based Practice in Indigent Defense, 12 Оніо ST. J. CRIM. L. 325, 334-35 (2015).

151. Moore \& Davies, supra note 80 , at 352 tbl.1. 
the Indigent Defense Research Association. ${ }^{152}$

The foregoing factors create significant barriers to fulfilling TIDC's mission of conducting data-driven analysis and improvement of public defense representation. TIDC faces additional hurdles due to the sheer size, diversity, and complexity of the state's public defense systems. The emphasis here is on plural systems. Texas is among the slim minority of states that continues to shift primary responsibility for the provision of public defense to counties. ${ }^{153}$ The state has 254 counties $^{154}$ that are responsible for $87 \%$ of public defense funding. ${ }^{155}$ That is the largest number of counties ${ }^{156}$ with the second largest population ${ }^{157}$ and land mass $^{158}$ of any state in the nation. Moreover, most of those 254 counties do not have centralized public defender offices staffed by salaried attorneys; instead, they provide public defense through judicial appointment of individual members of the private defense bar. ${ }^{159}$

Obtaining accurate data from people and systems operating at such a granular level and with such massive scope would be a daunting enterprise even with ample resources. However, as indicated in the previous section's discussion of fee caps in felony cases, resources for public defense in Texas put the state at the opposite end of the spectrum. Indeed, as TIDC was planning the Comal County counsel choice project, the state ranked "near the bottom nationally in per capita funding for indigent defense." 160 At the same time, TIDC was urging legislators to return funds they had diverted from TIDC (or to be more precise, from fees that the counties extract from people convicted of crimes in Texas courts, then send to TIDC, then receive back from TIDC as the state's sole contribution to public defense).$^{161}$

Given the number, size, and complexity of the barriers to undertaking datadriven reform of public defense across Texas, the fact that TIDC earmarked

152. Id. at 347 n.9.

153. The most recent data indicate that by 2013 " 28 states and the District of Columbia had state-administered indigent defense programs[.]” Suzanne M. Strong, U.S. Dep’t Just., State ADMINISTERED InDigent Defense SyStems, 2013, at 1 (2016), available at https://www.bjs.gov/ content/pub/pdf/saids13.pdf [https://perma.cc/J3PR-BFJ7]; see also IsSUE BRIEF, supra note 106, at 2 fig. 1.

154. Texas Almanac, TeX. StAte Historical Ass'N, http://texasalmanac.com/topics/factsprofile [https://perma.cc/S2Q5-W4Y7] (last visited Nov. 3, 2017).

155. IsSUE BRIEF, supra note 106, at 2 fig. 1 (tracking funding).

156. Which States Have the Most and Least Counties, US-CounTIES.COM (Jan. 3, 2013 2:51

$\mathrm{AM})$, http://www.us-counties.com/article/which-states-have-the-most-and-least-counties/ [https://perma.cc/FS3H-LDTX].

157. US States-Ranked by Populations 2017, World Population ReV., http:// worldpopulationreview.com/states/ [https://perma.cc/77EX-MCJS] (last visited Nov. 6, 2017).

158. U.S. States By Size, WORLD ATLAS, http://www.worldatlas.com/aatlas/infopage/ usabysiz.htm [https://perma.cc/C3XX-CCQP] (last visited Nov. 6, 2017).

159. See IsSUE BRIEF, supra note 106.

160. See Bethke, supra note 138.

161. See supra notes $138-40$ and accompanying text. 

TO CHOOSE COUNSEL

scarce resources for the counsel choice project demonstrates the project's high priority to the agency. In terms of how those funds were used, about $70 \%$ of the $\$ 200,000$ TIDC allocation was expended by the end of 2015. ${ }^{162}$ Some of that funding was awarded to Dean Lefstein and the Justice Management Institute (JMI). Each was the sole bidder for a consulting role in project design and in research and evaluation, respectively, ${ }^{163}$ as permitted by Texas law when services require specialized training, experience, or skill. ${ }^{164}$

The request for proposals on the project design contract required years of experience creating and managing public defense systems as well as "demonstrated expertise and [a] publication record in indigent defense delivery systems involving client control over attorney selection as practiced in such common law nations as England, Scotland, New Zealand or Canada." ${ }^{165}$ Dean Lefstein amply satisfied those requirements. ${ }^{166}$ With respect to the project evaluation contract, JMI is one of several major national organizations with extensive experience providing research, training, and technical assistance for legal systems, typically with support from government or foundation grants, ${ }^{167}$

162. Indigent Defense Data for Texas: Comal County: Discretionary Grants, Tex. InDIGENT Def. Comm'n, http://tidc.tamu.edu/public.net/Pages/CountyDashboard.aspx?cn=Comal [https://perma.cc/M9AF-44NF] (last visited Oct. 29, 2017).

163. State of Tex., Cnty. of Comal, Term Minutes of the Comal County COMmissioners Court MeEting 7-8 (Aug. 1, 2013), http://www.co.comal.tx.us/CCT-Minutes/ 2013/20130801.pdf [https://perma.cc/W7BR-SHHR] [hereinafter TERM MinUtes 2013].

164. Robert T. “Bob” Bass, Pitfalls For the Unwary -Bidding, Nepotism And Ethical Rules 1-2, Presentation to the 87th Ann. Conf. of the West Tex. Cnty. Judges \& Comm'r Ass'n (Apr. 2016), https://www.county.org/member-services/education-andtraining/presentations/Documents/2016-West $\% 20$ Texas\%20CJCA/3.004\%20Regulations\%20and\% 20Legal\%20Issues\%20-\%20Bass.pdf [https://perma.cc/W7BR-SHHR] (last visited Nov. 6, 2017) (citing Tex. Loc. Gov’t $\S 262.024$ ). TIDC assured the Comal County Purchasing Director that since the project design role involved "a highly specialized art . . receiving one response was not surprising.” TERM MINUTES 2013, supra note 163, at 7-8.

165. Cnty. of Comal, Tex, Request for Proposal \#2013-300: Indigent Defense Program Design Consultant 17, available at http:/www.co.comal.tx.us/Purchasing/2013/ 2013-300/2013-300.pdf [https://perma.cc/KC5X-D5TZ] (last visited Nov. 6, 2017).

166. TERM MINUTES 2013, supra note 163, at 7-8; see Lefstein, supra note 13, at 840-42.

167. Just. MGMt. Inst., http://www.jmijustice.org/ [https://perma.cc/5SML-99G8] (last visited Nov. 6, 2017); see supra note 126 and accompanying text (discussing work of Texas A\&M University's Public Policy Institute); see also Andrea M. Marsh, Nat'L Ass'N Of Crim. Def. Lawyers, State of Crisis: Chronic Neglect and Underfunding for Louisiana's Public DEFENSE SYSTEM (2017), available at https:/www.nacdl.org/louisianapublicdefense/ [https:// perma.cc/52BU-F4MD] (last visited Nov. 6, 2017) (discussing work of the NACDL); RAND CORP., http://www.rand.org/jie/justice-policy.html [https://perma.cc/A6GH-SET6] (last visited Nov. 6, 2017); URBAN INST., http://www.urban.org/about [https://perma.cc/A6GH-SET6] (last visited Nov. 6, 2017); VERA INST. OF JUST., https://www.vera.org/ [https://perma.cc/VJ6Z-WZY6] (last visited Nov. 6, 2017); 6AC \& Our Work, SiXTH AMEND. CTR., http://sixthamendment. 
and had partnered with TIDC on the unsuccessful federal grant application to study counsel choice in Texas. ${ }^{168}$

The project's Advisory Panel included several of the major organizations other than JMI that focus on research and consulting in legal systems, along with representatives from other organizations such as bar associations and several individual Texas attorneys. ${ }^{169}$ As planned during the project's inception, the Advisory Panel also included Marc Levin of the Texas Public Policy Foundation, whose email in the fall of 2010 sparked TIDC interest in counsel choice, and the Cato Institute's Tim Lynch, who moderated the December 2014 Federalist Society podcast and penned numerous editorials about the project thereafter. ${ }^{170}$ Additional Advisory Panel members came from branches of state government and the Texas Fair Defense Project, a local nonprofit focused on improving the quality of criminal defense across the state. ${ }^{171}$ As the site selection process unfolded, judges and court administrators from Comal County participated in project planning, as did local prosecution and defense attorneys. ${ }^{172}$

\section{Choosing Choice: The Role of Comal County Stakeholders}

Project organizers partnered with Comal County for several reasons. First, TIDC had concerns about the lack of incentives for quality performance in that county and about the lack of attorney independence from the judiciary. ${ }^{173}$ Second, the County's size and location made a pilot study relatively manageable. ${ }^{174}$ The County's size also made it more likely that defendants would have better access to information about a relatively small pool of lawyers from whom defendants

org/about-us/ [https://perma.cc/R58F-6ZN5] (last visited Nov. 6, 2017) (discussing services); Public Defense Resources: Defender Legal Services, NAT'L Legal Aid \& Def. Ass'N, http://www.nlada.org/tools-and-technical-assistance/public-defense-resources [https://perma.cc/K8EN-UL42] (last visited Nov. 6, 2017) (discussing resources); Boruchowitz Aff., 31-39, https://www.splcenter.org/sites/default/files/documents/2017.05.04_boruchowitz_ report.pdf [https://perma.cc/G57G-EXBB] (last visited Nov. 6, 2017) (discussing work of The Defender Initiative at the Seattle University School of Law); Press Release, U.S. Dep't of Justice Office of Pub. Affairs, Attorney General Holder Announces \$6.7 Million to Improve Legal Defense Services for the Poor (Oct. 30, 2013), https://www.justice. gov/opa/pr/attorney-general-holderannounces-67-million-improve-legal-defense-services-poor [https://perma.cc/QGB8-VRDT] (describing 2013 awards totaling $\$ 1.8$ million to some of these organizations).

168. TERM MinUtes 2012, supra note 142, at 7.

169. Nugent-Borakove et AL., supra note 8, at 57 app. C.

170. Tex. Indigent Def Comm'n, Comal County Client Choice Project Advisory Panel \& Project Team (as of March 27, 2017) (on file with the author) [hereinafter Panel \& Project TEAm]; see also Podcast, supra note 83.

171. Panel \& Project Team, supra note 170.

172. Nugent-BoraKove et AL., supra note 8 , at 1.

173. Podcast, supra note 83, at 20:08-20:23.

174. NugENT-BoraKove ET AL., supra note 8 , at 6. 
could choose. ${ }^{175}$

The final reason for choosing Comal County was that key county stakeholders (judges, court administrators, defense lawyers, and the local prosecutor) agreed to participate. ${ }^{176}$ Available records of their discussions show particular enthusiasm from the District Attorney, who emphasized the importance of attorney-client trust and communication as well as her own need to focus on prosecuting cases instead of worrying about substandard defense representation. ${ }^{177}$ Other stakeholders anticipated that better attorney-client relationships would increase efficiency by reducing delays and appeals. ${ }^{178}$ Participants also expressed confidence that oversight from TIDC and trained researchers would prevent the project from creating any unacceptable risks. ${ }^{179}$ Similar personal respect for TIDC and Dean Lefstein tempered at least some opposition to the project from at least some members of the national public defender community. ${ }^{180}$

Participants also were excited about Comal County being "in the spotlight" for innovation. ${ }^{181}$ Among the 254 counties in Texas, Comal is medium-sized and flanked by two major urban areas (San Antonio and Austin). ${ }^{182}$ Federal census data available at the time of the study reported a population of 108,000 that was approximately $70 \%$ white and $26 \%$ Latino-Hispanic with a median income of $\$ 65,839$ and a $10 \%$ poverty rate. ${ }^{183}$

Given these demographics and the fact that $91 \%$ of Texas counties report a higher poverty rate, ${ }^{184}$ it may be unsurprising that Comal County's public defense system is relatively compact. Four judges handle felony cases and two handle misdemeanors. ${ }^{185}$ Table 2 illustrates the County's 2015 misdemeanor and noncapital felony caseload. ${ }^{186}$

175. Podcast, supra note 83, at 44:12-44:57.

176. Nugent-BoraKove eT AL., supra note 8, at 50 app. B.

177. TERM MinUtes 2012, supra note 142, at 8-9.

178. Id. at $6-10$.

179. Id.

180. See Lewis, supra note 123.

181. TERM MinUtes 2012, supra note 142, at 6.

182. Id. at 10 .

183. See State \& County Quickfacts Comal County Report, U.S. CEnsus BurEAu, http://quickfacts.census.gov/qfd/states/48/48091.html [http://perma.cc/SS2V-2JVN] (last visited Aug. 5, 2017).

184. Texas Poverty Rate by County (Table), InDEX Mundi, https://www.indexmundi.com/ facts/united-states/quick-facts/texas/percent-of-people-of-all-ages-in-poverty\#chart [https://perma.cc/2BZT-QALV](last visited Nov. 3, 2017).

185. NugENT-BoraKOVE ET AL., supra note 8, at 6.

186. Id. at 6,11 . 
Table 2

FY 2015 Criminal Caseload Distribution, Comal County, Texas

\begin{tabular}{|c|c|c|c|c|c|}
\hline & New & $\begin{array}{c}\text { Pending } \\
\text { Midyear }\end{array}$ & $\begin{array}{c}\text { Handled } \\
\text { Feb.- } \\
\text { Dec. }{ }^{187}\end{array}$ & Closed & $\begin{array}{c}\text { Assigned } \\
\& \\
\text { Paid }\end{array}$ \\
\hline Misdemeanors & 2065 & 3002 & 619 & 1957 & 901 \\
\hline Felonies & 594 & 737 & 485 & 501 & 445 \\
\hline
\end{tabular}

Between 2012 and 2016, 76\% of County felony cases required governmentpaid defense counsel; the range over those five years was from $58 \%$ to $100 \%$. ${ }^{188}$ Comal County does not have a public defender office with salaried attorneys. Instead, the judges keep three separate lists of lawyers deemed qualified to handle serious felonies, lower-level felonies, and misdemeanors. Before the counsel choice pilot study began, if a defendant needed a government-paid lawyer, the appointing judge would assign cases on a rotating basis. ${ }^{189}$ Exceptions could be made if, for example, there was a language barrier or other concerns about the defendant-defender match. ${ }^{190}$

Although the official report is not completely clear, it appears that between thirty-five and fifty-five private lawyers were on the Comal County assignedcounsel lists at the time of the counsel-choice pilot study. ${ }^{191}$ It is also unclear whether all of the attorneys on these lists participated in the study, although the study authors state that the twenty-two who participated in the postimplementation evaluation comprised a "large sample" and a "broad crosssection" of qualified counsel. ${ }^{192}$

As discussed in Part I.A, compensation rates for participating attorneys were so low, particularly in light of the state's own workload study, as to call into question both the meaning of counsel choice for any particular defendant and its potential as a strategy for obtaining sustainable improvements in public defense. Part III explains other limitations on the counsel choice project. One set of limitations involves the same austerity principle that is at work in the systematic underfunding of public defense. Another set of limitations involved regulatory checks on the free-market principles that originally animated the study. Of the two types of limitations, it is the austerity principle that came closest to eliminating meaningful choice while also limiting the ability to draw generalizable conclusions from the data.

187. Id. at 9-10. This was the ten-month period after which JMI initiated post-implementation evaluation.

188. Indigent Defense Data for Texas: Comal County Datasheet: 2001-2016, TEX. INDIGENT DeF. CoMm'N, https://tidc.tamu.edu/public.net/Reports/DataSheet.aspx?cid=46 [https://perma.cc/ R54K-AMC5] (last visited Nov. 3 2017).

189. NugENT-BoraKove ET AL., supra note 8, at 10-11.

190. Id. at 6, 54; see also TERM MinUtes 2012, supra note 142, at 8-9.

191. Nugent-BoraKove ET AL., supra note 8, at 11.

192. Id. at $10-11$. 


\section{LIMITATIONS ON PROJECT DESIGN AND IMPLEMENTATION}

Despite the pre-implementation emphasis on using vouchers to import freemarket principles into public defense, counsel choice in Comal County was not untrammeled by government regulation. To the contrary, state law confined counsel choice to attorneys previously deemed qualified for case assignments. ${ }^{193}$ Free-market principles were further checked by a decision to limit information provided to defendants about lawyers in order to avoid "disseminating material that was unverified and might be in violation of ethical rules restricting lawyer advertising." 194 As a result of this decision, defendants were given a binder of forms relating ten basic pieces of information about each participating attorney such as his or her name, law school, and percentage of practice that involved public defense cases in the previous year. ${ }^{195}$

Several facts about this regulatory limitation are notable. First, it was imposed over the objection of the lead magistrate and other members of the courtroom work group who were concerned that it would prevent informed choice. ${ }^{196}$ Second, it was imposed despite alternative methods for detecting and policing potential ethics violations. ${ }^{197}$ Third, post-testing with participating defendants indicates that they did not find it easy to obtain information to choose counsel and that they relied on factors such as attorney reputation, recommendations, and prior experience to do so. ${ }^{198}$ Finally, it does not appear that any research supports the assertion that the type and quality of information in the binders "mirrored" the information available to people who could afford to hire counsel. ${ }^{199}$

These study limitations are significant, but they pale in comparison to those created by resource constraints. The first resource-driven limitation calls the meaning of counsel choice into question because it compounded the information deficit that was created by restricting the available data on participating attorneys to the binder of ten-point professional biographies. Due to resource constraints, project leaders reduced the available time for defendants to exercise choice from the forty-eight hours required by the project plan to fifteen minutes. ${ }^{200}$ This $99.5 \%$ reduction was due to complaints from the chief magistrate and jail personnel that administering counsel choice was too "burdensome" and "time consuming." 201

193. Id. at 3-4; see also Moore, supra note 1, at 1761-64 (predicting this outcome).

194. Nugent-BoraKove ET AL., supra note 8, at 15 n.24, 16 n.27, 53-55.

195. Id at 53-55.

196. Id. at 16 .

197. See id. at 16 n.27 (citing Texas Disciplinary Rules of Professional Conduct, Rule $7.05(\mathrm{a})(3))$.

198. Id at 16 .

199. Id. at $15-16,53$.

200. Id. at 15,55 n.69.

201. Id. at 55 . 
Although the official report does not acknowledge the fact, imposition of this time constraint based on these administrability concerns - particularly in a jurisdiction that was specifically selected for project implementation based on what is represented to be broad support from system leadership - belies the claim that counsel choice "is a viable model that can be replicated" since there is "no evidence of adverse effects . . . to cost effectiveness and administration of the justice system." ${ }^{202}$ To the contrary, it appears that there were significant adverse effects, that is, the "burdensome," "time-consuming" and apparently costly steps involved in administering counsel choice.

It also appears that those significant adverse effects were eliminated shortly after they became evident, and that a meaningful opportunity to exercise informed choice disappeared along with them. These transformative decisions fulfilled the commitments to austerity in public funding and cost containment that informed the project's inception and development. ${ }^{203}$ They are consistent with the failure to provide additional resources to compensate attorneys for the extra investments of time and effort that project designers anticipated would occur in response to newly-released market pressure. ${ }^{204}$

These aspects of study design and implementation make another passage in the official study report all the more noteworthy. The report states that it was an "unanticipated implementation phenomenon" that counsel choice would result in excessive caseloads for some lawyers and that the caseload increases "likely had an impact" on the quality of their representation. ${ }^{205}$ This statement is remarkable because the libertarian, free-market theory had predicted increased caseloads for lawyers perceived to be better-performing. ${ }^{206}$ It should have been equally predictable that the project's commitment to austerity in public funding would limit the capacity of those lawyers to improve performance by denying them any additional resources to support increased investments of time and effort.

Nor were these the only resource-driven project limitations that deserve discussion. A number of other constraints affected JMI's investigation into whether counsel choice affected the quality of public defense representation, stakeholder satisfaction, and case outcomes. ${ }^{207}$ Unfortunately, some of the more significant limitations are not acknowledged in the official study report.

The additional project limitations became evident as follows. To conduct the process and outcome assessment, JMI conducted a baseline evaluation in 2013 before counsel choice was implemented and a follow-up evaluation that began in December 2015 after the counsel choice program had been underway for ten months. ${ }^{208}$ The evaluations used mixed methods for data collection, ${ }^{209}$ with

\author{
202. Id. at ii. \\ 203. See supra Part II.A. \\ 204. See supra notes $114-17$ and accompanying text. \\ 205. Nugent-Borakove ET AL., supra note 8, at iii. \\ 206. See supra notes 114-17 and accompanying text. \\ 207. Nugent-BoraKOve ET AL., supra note 8, at ii. \\ 208. Id. at 9 . \\ 209. See generally John W. Creswell \& Vicki L. Plano Clark, Designing and
}



TO CHOOSE COUNSEL

qualitative data obtained through interviews and quantitative data obtained through surveys and a search of online court records. ${ }^{210}$

The interviews included "representatives from all of the major stakeholder groups," defined as judges, court administrators, the District Attorney, and defense lawyers. ${ }^{211}$ Notably, this definition of "all of the major stakeholder groups" excluded people who need public defense representation. Instead of conducting interviews or using focus groups to tap the perceptions of that stakeholder group, researchers relied exclusively on surveys. ${ }^{212}$ The surveys asked for demographic information, criminal history, and perspectives on procedural justice and attorney performance. ${ }^{213}$

JMI did not conduct focus groups or interviews with defendants due to the challenges involved, including the difficulty of obtaining Institutional Review Board approval. ${ }^{214}$ To be sure, people facing criminal charges are a notoriously hard-to-reach population for researchers. ${ }^{215}$ Indeed, JMI's first survey attempt had a $1 \%$ response rate, which was inadequate to generate sufficient data; adding the offer of a $\$ 5$ Walmart gift card as an incentive generated enough participation to move the study forward. ${ }^{216}$

Without understating the significance of the challenges involved in conducting mixed methods research in this setting or questioning the utility of the defendant survey used in this study, it bears mention that other studies with defendant populations have supplemented quantitative methods with interviews and focus groups. Those studies indicate that challenges to conducting such mixed methods research can be surmounted and that doing so can yield valuable insights. ${ }^{217}$ It appears that the counsel choice project lacked sufficient time and resources to do that work.

This deficit is important in part because the project did not involve random sampling of a large population. Whether or not random sampling deserves to be called "the gold standard" for social science research, ${ }^{218}$ the method does improve

Conducting Mixed Methods Research (Helen Salmon et al. eds., 3d. ed. 2017).

210. Nugent-Borakove ET AL., supra note 8, at 9.

211. Id.

212. Id. at 9,11 .

213. Id. at 11-13, 26-27.

214. Telephone interview with Elaine Nugent-Borakove (May 23, 2017) [hereinafter Telephone Interview]; see also Carol A. Heimer \& JuLeigh Petty, Bureaucratic Ethics: IRBs and the Legal Regulation of Human Subjects Research, 6 ANN. REV. L. Soc. SCI. 601, 606-11 (2010) (discussing difficulties of complying with Institutional Review Board requirements).

215. Christopher Campbell et al., Unnoticed, Untapped, and Underappreciated: Clients' Perceptions of Their Public Defenders, 33 BeHAV. ScI. \& L. 751, 765 (2015).

216. Telephone Interview, supra note 214.

217. See, e.g., Campbell et al., supra note 215, at 752-53; Sandys \& Pruss, supra note 47, at $458-61$.

218. See Robert J. Sampson, Gold Standard Myths: Observations on the Experimental Turn in Quantitative Criminology, 26 J. QuANT. CRIMINOLOGY 489 (2010) (critiquing "gold standard" 
control over confounds, or "unknown and unmeasured variables" that can affect study results. ${ }^{219}$ Instead of using a random sample, the Comal County Counsel choice project involved people who opted in or out by either choosing counsel or letting the judge choose counsel for them.

Nor did the project involve random sampling of people in any of the three subcategories of defendants who provided survey data. The first group was surveyed pre-implementation; they had no opportunity to choose counsel. ${ }^{220}$ The two post-implementation groups comprised people who had the opportunity to choose counsel; group two "chose to choose" ${ }^{221}$ while group three declined the opportunity and let the court choose counsel for them. ${ }^{222}$ Members of all three groups were self-selected as research subjects by participating in the surveys instead of being selected through random sampling. ${ }^{223}$

Additional research, including qualitative research involving interviews or focus group discussions with members of all three groups, could have improved understanding of their perceptions and experiences. ${ }^{224}$ More importantly, given that this was a nonrandom study, additional research could have explored whether self-selection introduced confounds, that is, factors other than counsel choice that explain any differences in perceptions, experiences, and case outcomes. ${ }^{225}$

For example, people who chose to choose counsel might have been more optimistic, more inclined to engage actively with the world around them, or simply more concerned about their specific cases than people who let the court choose their lawyers. Such differences could lead people to be more or less inclined to, for example, push for more frequent and longer meetings with their lawyers or to offer information that could lead to better plea deals.

The possibility that such confounds accompanied self-selection is apparent in the study data. Among the $72 \%$ of defendants who chose to choose their lawyers, $47 \%$ had felony charges and $53 \%$ were charged with misdemeanors. ${ }^{226}$ But among the $28 \%$ who let the court choose their lawyers, that ratio changed dramatically: only $33 \%$ had felony charges, while $67 \%$ were charged with misdemeanors. ${ }^{227}$ It is reasonable to hypothesize from these data that people who chose to choose counsel were more invested in the outcomes of their higher-stake

label).

219. David P. Farrington \& Brandon C. Welsh, A Half Century of Randomized Experiments on Crime and Justice, 34 CRIME \& JUST. 55, 58 (2006).

220. NugENT-BorakOve ET AL., supra note 8, at 11-12.

221. Id. at 11-12.

222. Id.

223. Id. at 10-13.

224. See Campbell et al., supra note 215, at 767-68; Sampson, supra note 218, at 496-99 (arguing for multimethod research in criminology).

225. See generally Alan Agresti \& Barbara Finlay, Statistical Methods for the Social Sciences, Section 10.2 (3d ed. 1997); Judea Pearl, Causal Inference in Statistics: An Overview 3 StAT. SURV. 96 (2009).

226. Nugent-BoraKove et AL., supra note 8, at 11.

227. Id. 

TO CHOOSE COUNSEL

cases, which might in turn lead to higher levels of engagement with counsel and other behaviors and consequences discussed above. Absent a method for identifying and evaluating such factors, there is no way to know whether they are causing any observed differences between choosers and non-choosers-or whether they do so independently or in some relationship with each other or with the exercise of counsel choice.

Thus, it is important to detect such confounds lest they lead to mistaken inferences of causal relationships - e.g., an inference that counsel choice has a particular effect - in violation of the old adage that "correlation is not causation." To be sure, like randomization, additional research to detect confounds takes time and money. Again, given JMI's experience with justice system research, ${ }^{228}$ it seems likely that the failure to invest in these methods was driven by resource constraints. Indeed, when attempting to explain the apparent failure of counsel choice to improve client satisfaction, the official study report recommended future investigation into the possibility that people who chose to choose their lawyers "simply had higher expectations" for counsel performance. ${ }^{229}$ Moreover, when asked about whether other confounds like the ones sketched above might have affected the study, the lead author conceded that this was possible and that "the types of data that we had did not allow us to explore this further." 230

It also seems likely that resource constraints contributed to "confusion about who was responsible" for collecting survey data from defendants and to "logistical issues related to tracking defendants post-disposition" in order to obtain those data. ${ }^{231}$ Those problems in turn appear to have caused the study's most serious flaw: the small sample size of post-implementation survey data cannot support generalizable conclusions.

To be fair, the study report concedes that "generalizations should be made cautiously from many of the findings due [to] the sample size." ${ }^{.232}$ However, the nature and magnitude of the problem are not readily apparent in the official study report. Detection required close scrutiny of the reported data and consultation with the lead study author and with other social scientists. That inquiry led to the problem analysis below.

The report states that 119 people self-selected to participate in the defendant survey before counsel choice was made available, while sixty-eight participated in the post-implementation survey. ${ }^{233}$ Of the sixty-eight post-implementation respondents, $75 \%$, or fifty-one people, chose to choose their lawyers. ${ }^{234}$ That means that only seventeen respondents fit into the third category of research

228. Just. Mgmt. InSt., supra note 167.

229. Nugent-BoraKove ET AL., supra note 8, at 31.

230. E-mail from Elaine Nugent-Borakove, President, Just. Mgmt. Inst., to Janet Moore, Professor of Law (May 31, 2017, 1:02 PM) (on file with author).

231. Nugent-BoraKove et AL., supra note 8, at 12 n.22.

232. Id. at 46 .

233. Id. at $9-11$.

234. Id. at 11-12. 
subjects: people who had an opportunity to choose counsel but let the court choose for them instead.

Although the official report does not acknowledge the problem, seventeen respondents is an inadequate number to support the comparative analysis across the three categories of defendants that was incorporated into the project design. ${ }^{235}$ Nor does the official report acknowledge that, because the sample size was too small, the researchers altered the project design by merging the survey responses of the seventeen people in the third category (people who had an opportunity to choose but let the judge choose for them) with the survey responses of the 119 people in the first category (people who participated in the survey before implementation of counsel choice, and who therefore had no opportunity to choose) to create a fourth category labeled "Non-Counsel Choice Participants." 236

Analysis of the survey data then compared the responses of people in the second category (people who had an opportunity to choose counsel and did so) with the new, merged, fourth category of "Non-Counsel Choice Participants." This move creates a number of problems. Most obviously, the key variable (response to the opportunity to choose counsel) is no longer key. Instead of comparing two groups of people based on that variable, the study compares one group for whom the variable was present with a hybrid group for about $90 \%$ of whom the variable was absent. It is as if the research switched from an apples-toapples comparison by substituting plums-to-pluots mid-study. Moreover, this $10 \%$ hybridization raises the possibility of compounded negative confounding variables. That is, people who have the option to choose counsel, but who allow judges to choose for them, may have characteristics that shape their perceptions, behaviors, and experiences in ways that the study does not control for and that also exist in the original sample with which they are merged.

It might be possible to justify this deviation from project design and to investigate any potential impacts on reported results. However, the absence of such discussion from the official study report and the report's failure, at minimum, to alert readers that the issue existed are concerning. The report's silence on this point is particularly noteworthy because the report did not undergo peer review before publication in an academic journal, but instead seems to be aimed at lay readers and, more particularly, at policy makers who might be encouraged to shape decisions based on claims that, on closer scrutiny, are not fully supported.

Moreover, as discussed in Part IV, decisions about whether and how to report variations between study design and implementation augment worries about other aspects of data reporting. Those aspects tend to emphasize the benefits of counsel choice without acknowledging how the same data indicate serious systemic problems, many of which trace to the same resource constraints and austerity principles that limited the study's scope and results.

235. Email from Nugent-Borakove, supra note 230.

236. Telephone Interview, supra note 214; E-mail from Nugent-Borakove, supra note 230. 

TO CHOOSE COUNSEL

\section{RESULTS AND AVENUES FOR FUTURE RESEARCH}

Although the study report describes the investment of significant time and effort in qualitative research with judges, court administrators, and lawyers, the bulk of the report focuses on defendant impressions as reported in the survey data. Part III of this Article noted some significant limitations in those data, which affect their ability to support generalizable conclusions about whether counsel choice affects the quality of public defense representation. Before turning to additional concerns about the reporting of the survey data, this Part will make a few brief points about the qualitative data.

First, $65 \%$ of interviewees "reported that there had been no changes in courtroom practices and representation" after counsel choice became operative. ${ }^{237}$ Of the minority who did report changes, some could not specify what they were. ${ }^{238}$ Additionally, the nature of other comments raises the question of whether priming during the process that generated a commitment to participate led to confirmation bias such that perceptions matched expectations independently of objectively verifiable improvements. ${ }^{239}$

Qualitative data from defense lawyers raise separate concerns. Those data indicate that counsel choice creates incentives that can aggravate instead of ameliorate existing resource deficits. Those incentives are predictable given the theory that informed the counsel choice study, including the specific commitment to austerity in funding public services.

The first problem is that counsel choice appears to aggravate instead of ameliorate preexisting conflicts of interest. The conflict of interest at issue does not involve trying to please a judge instead of a client in order to secure future appointments. The conflict of interest involves the triaging of client interests that too many defenders engage in because of excessive workloads and inadequate resources. ${ }^{240}$

The problem is exacerbated when lawyers represent paying clients as well as people who need appointed counsel. ${ }^{241}$ Some research supports the predictable

237. Nugent-BoraKove ET AL., supra note 8, at 24.

238. Id.

239. See id.

240. See Norman Lefstein, Am. Bar Ass'n Standing Comm. on Legal Aid \& Indigent Defendants, Securing Reasonable Caseloads: Ethics And Law in Public Defense 4 n.6, 30, 61-62, 228 (2011), available at https:/www.americanbar.org/content/dam/aba/publications/ books/ls_sclaid_def_securing_reasonable_caseloads.authcheckdam.pdf [https://perma.cc/AWV3KX27]; Tigran W. Eldred, Prescriptions for Ethical Blindness: Improving Advocacy for Indigent Defendants in Criminal Cases, 65 Rutgers L. Rev. 333, 348 (2013); see also NAT'L Right to Counsel Comm., The Constitution Project, Justice Denied $95-97$ (2009), available at https://constitutionproject.org/wp-content/uploads/2012/10/139.pdf[https://perma.cc/79BN-GYFY] (discussing the dearth of quality client contact as a result of excessive caseloads and inadequate resources).

241. See The Constitution Project, supra note 240, at 195; Nugent-Borakove et Al., 
conclusion that criminal defense lawyers are incentivized to invest more time and effort in higher-paying cases instead of lower-paying cases. ${ }^{242}$ Because the study design for the Comal County counsel choice project included notice to the lawyers when they had been chosen by someone who needed public defense representation, some lawyers reported that they felt greater responsibility and concern for the "choosers." 243 Although $68 \%$ of interviewed defenders reported that counsel choice did not alter their representation, ${ }^{244}$ the comments about special concern for "choosers" reflect a risk that, absent adequate resources to support workloads, counsel choice could simply multiply the conflicts that are inherent in triaging client interests, with paying clients at the top of the heap, "choosers" in the middle, and "non-choosers" at the bottom.

The defender interviews reveal a second way that counsel choice can aggravate system deficits. This can occur when people who could otherwise scrape together the resources to hire counsel on the private market instead enter the public defense system because they can choose the same lawyer "for free."245 One attorney reported that a beneficiary of this unexpected windfall responded by saying, "How lucky is that!?"246 Three of the twenty-two lawyers interviewed stated that this shift from private to public funding occurred in their cases, although the study authors cautioned that this phenomenon did not appear to be generalizable as an impact of counsel choice. ${ }^{247}$

Similar specific cautions about generalizability seldom accompanied reports of the survey data, despite the concerns about those data that are discussed in Part III of this Article. To be sure, this section of the official study report begins by warning that the overall evaluation "presents a mixed picture" that "challeng[es] many of the hypotheses about the advantages of the Client Choice model, particularly the benefits to defendants. ${ }^{.248}$ The report continues with the caution that the survey responses and related findings "suggest the need for further analysis . . . with a larger sample." 249 However, the report tends to highlight advantages of counsel choice without acknowledging serious problems indicated by the same data or the apparent connection between those problems and systematic resource deficits. The following examples are not exhaustive.

The study reported that: "Client Choice does improve . . . timeliness of the first meeting between defense lawyer and client"; more specifically, that "the odds of Client Choice defendants meeting with their lawyers in-person within 7 days were 0.778 times greater than for non-Client Choice participants"; and that

supra note 8 , at 25 n. 35 .

242. Benjamin Schwall, More Bang for Your Buck: How to Improve the Incentive Structure for Indigent Defense Counsel, 14 OHIO ST. J. CRIM. L. 553, 557 (2017).

243. Nugent-Borakove ET AL., supra note 8, at 24.

244. Id. at 24-25.

245. Id. at 20 .

246. Telephone Interview with Dean Emeritus Norman Lefstein (Sept. 24, 2017).

247. Nugent-BoraKove ET AL., supra note 8, at 20.

248. Id. at 26 .

249. Id. 
"[t]his finding supports the idea that a choice model has an impact on lawyer behavior as it relates to timeliness of the first meeting." ${ }^{250}$ As discussed in Part III, however, claims about causality are undermined by a number of factors related to study design and implementation, including the unreported change in design analysis that resulted from an insufficient data sample.

Moreover, the same data set contains a much grimmer but untold tale. As Figure 1 illustrates, the strong majority of defendants who participated in the survey waited more than five days to see their lawyers. Sixty-five percent of "non-Client Choice participants" waited more than ten days to see their lawyers, as did nearly half of "Client Choice" participants. ${ }^{251}$ The scope and length of these delays are shocking, particularly given the importance of initiating pretrial release advocacy, case investigation, and counseling against self-incrimination as early as possible. ${ }^{252}$

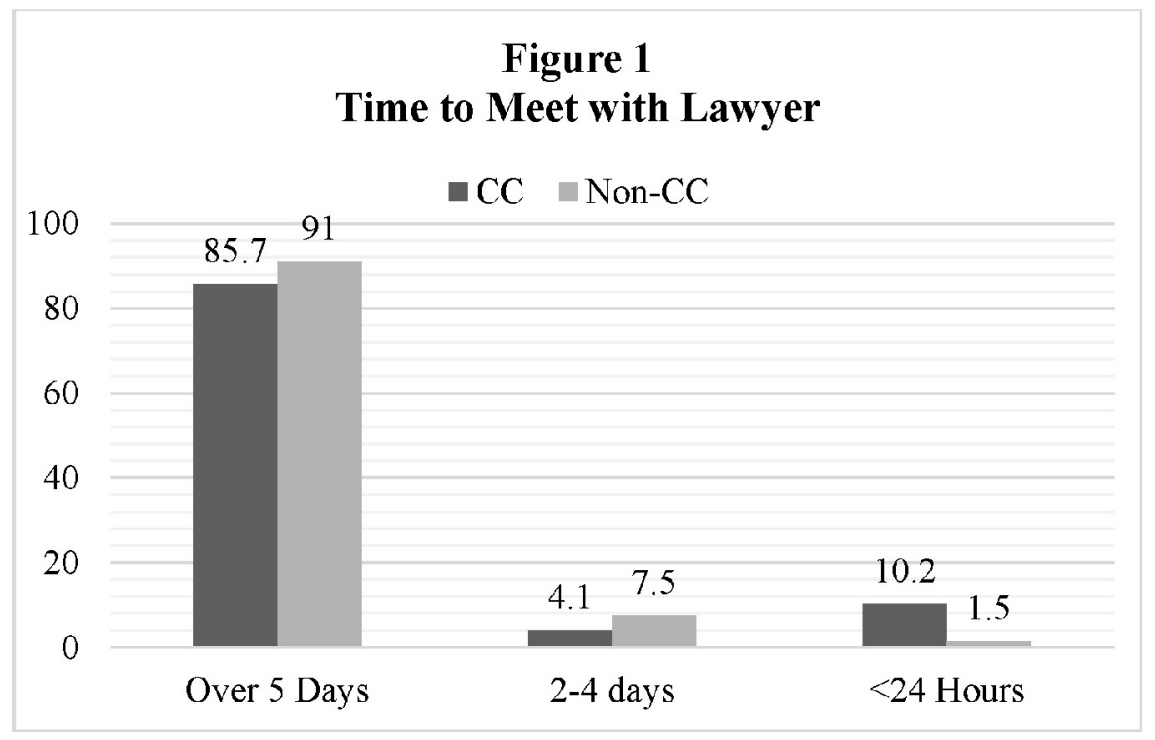

The report also states that "Client Choice cases were 2.96 times more likely

250. Id. at ii, $27,29$.

251. See id. (providing data).

252. See Rothgery v. Gillespie County, Texas, 554 U.S. 191, 210 (2008) (“a defendant subject to accusation after initial appearance is headed for trial and needs to get a lawyer working"); Paul Heaton et al., The Downstream Consequences of Misdemeanor Pretrial Detention, 69 STAN.L.REV. 711, 713 (2017) (describing harms from pretrial incarceration); D. Christopher Dearborn, "You Have the Right to an Attorney, " but Not Right Now: Combating Miranda's Failure by Advancing the Point of Attachment Under Article XII of the Massachusetts Declaration of Rights, 44 SuFfolK U.L. REV. 359, 360-61 (2011) (describing need for early access to counsel to protect rights against self-incrimination). 
than non-Client Choice cases to be disposed by a plea to a lesser charge than to go to trial" and comparable odds that choosers would receive community service instead of incarceration, with these data "provid[ing] strong support for the hypothesis that a choice model produces better case outcomes for defendants."253 Again, however, rearranging the same data along different vectors presents an unhappier story. As illustrated in Figure 2, differences between choosers and nonchoosers are swallowed up as nearly $90 \%$ of defendants in both categories are convicted as charged and comparable minorities obtain dismissals or lower-level convictions:

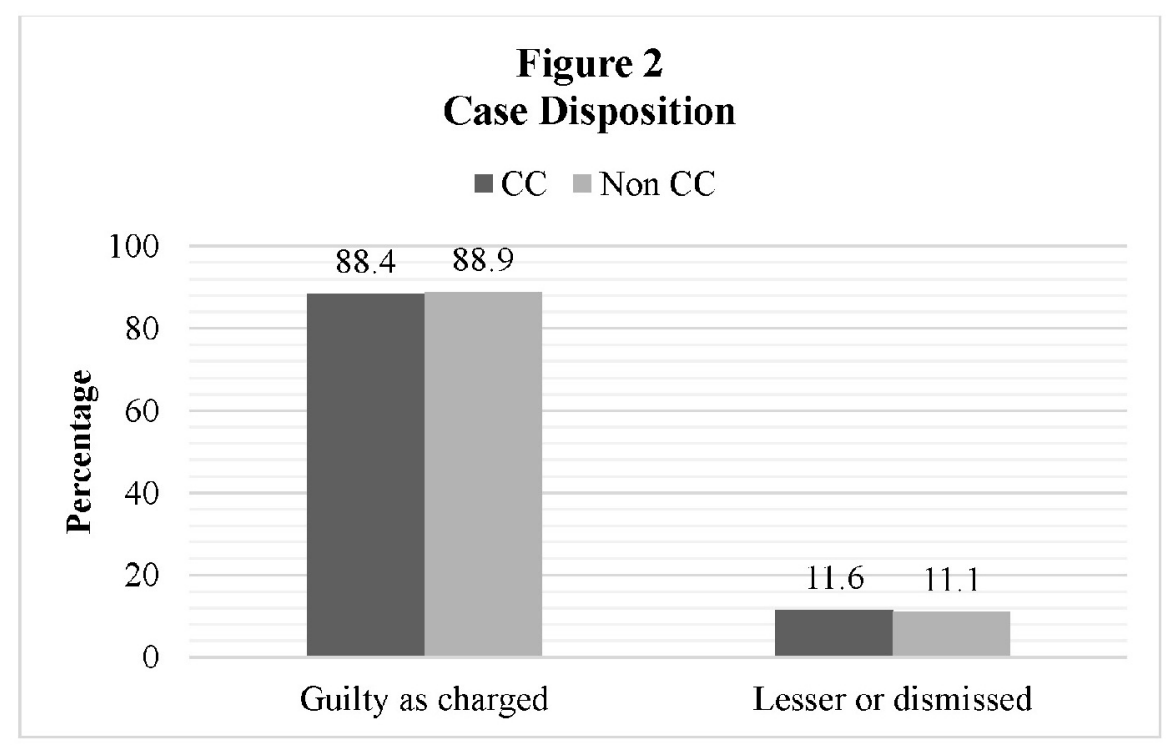

With respect to sentences, non-choosers enjoy a slight advantage over choosers in that only $9.9 \%$ are released on time served ${ }^{254}$ while just over $90 \%$ are subjected to incarceration, split sentences, community supervision, or diversion to treatment or community service; ${ }^{255}$ for choosers, those percentages are a bit worse (7.3\% and $92.7 \%$, respectively). ${ }^{256}$

Similar issues emerged in assessing the amount of time lawyers spent talking with defendants. An even larger majority of choosers (71\%) than non-choosers $(68 \%)$ reported talking for less than fifteen minutes with their lawyers. ${ }^{257}$ Counsel choice had no apparent impact on lengthening those conversations, on improving responsiveness to phone calls or meeting requests, in altering meeting locations,

253. NugENT-BoraKove ET AL., supra note 8, at 32-33.

254. Id. at 33 .

255. Id.

256. $I d$.

257. Id. at 28 . 
in perceptions of how hard lawyers were working, in client satisfaction, or in how lawyers treated defendants. ${ }^{258}$ As previously noted, in some instances where hypothesized advantages of counsel choice did not materialize in the data, study authors proposed that the "unanticipated" flow of cases to particular lawyers drove down the quality of their work. ${ }^{259}$

When presenting data on whether lawyers treated defendants with respect, the study reports that " $[\mathrm{m}]$ ore than twice as many Client Choice defendants as nonClient Choice defendants" agreed, and that the odds of that outcome for choosers versus non-choosers "were 0.44 times greater ... which was statistically significant." ${ }^{260}$ Again, as illustrated in Figure 3, the data contain another, arguably more significant story: nearly two-thirds of choosers and three-quarters of nonchoosers felt that they were not treated with respect. ${ }^{261}$

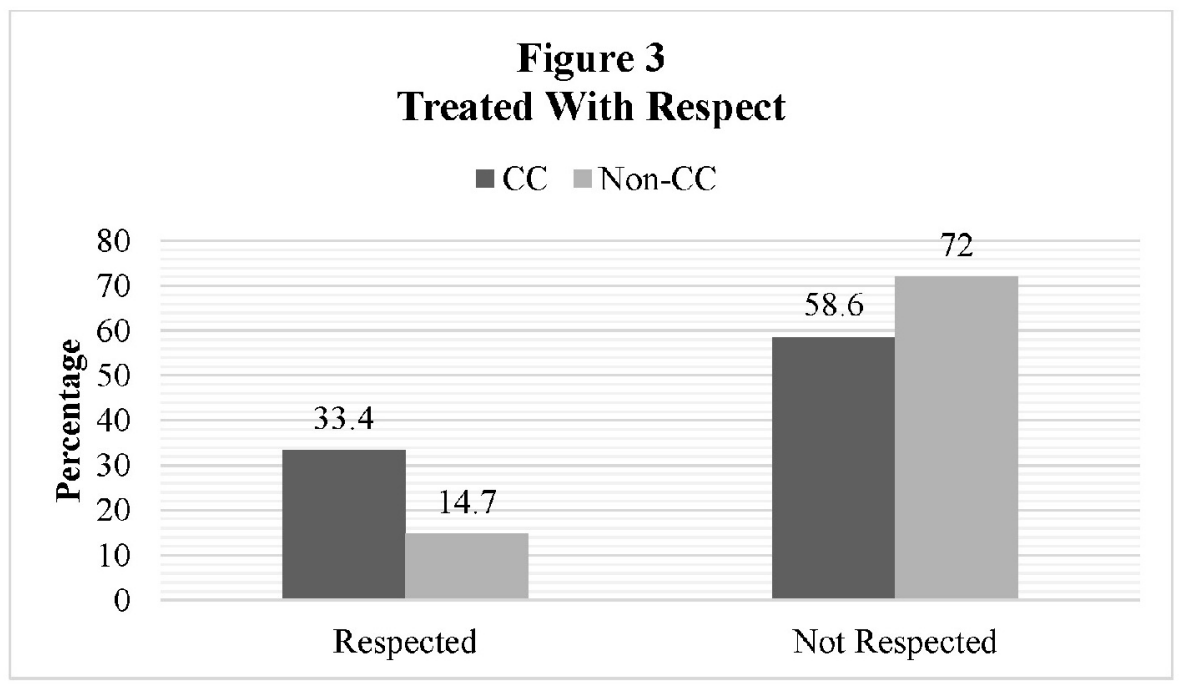

Similarly, while choosers were more likely than non-choosers to agree that

258. Id. at 29-36. Data reporting that a majority of defendants express satisfaction with counsel are consistent with other research. See Campbell et al., supra note 215, at 759. It is important to note, however, that the relationship between satisfaction and quality is complex and contested, including in research fields such as consumer sciences and medicine that are much further advanced on the issue than law. See generally Richard L. Oliver, Satisfaction: A Behavioral Perspective on the Consumer ( $2 \mathrm{~d}$ ed. 2010); Matthew P. Manary et al., The Patient Experience and Health Outcomes, 368 New Eng. J. Med. 201 (2013); Melissa Bekelja Wanzer et al., Perceptions of Health Care Providers' Communication: Relationships Between Patient-Centered Communication and Satisfaction, 16 Health Comm. 363 (2004).

259. Nugent-Borakove et AL., supra note 8, at iii, 29, 31.

260. Id. at 34 .

261. Id. 
their lawyers wanted what was best for them, majorities of both groups did not agree either with that proposition, ${ }^{262}$ with the statement that their lawyers kept them informed about their cases, ${ }^{263}$ or with the description of their lawyers as honest. ${ }^{264}$ The study reported that while a stronger majority of non-choosers $(57 \%)$ than choosers $(51 \%)$ felt that their lawyers took the time to listen to them, that difference, unlike differences favoring counsel choice, was found not to be statistically significant. ${ }^{265}$ On the other hand, the majority of non-choosers $(61 \%)$ over choosers $(52 \%)$ who felt that their lawyers clearly explained what was happening in their cases was found to be statistically significant. ${ }^{266}$

Figure 4 summarizes some of the foregoing discussion into a single illustration, which underscores several points. First, the dominance and dimension of unfavorable perceptions underscore the challenges facing public defense lawyers and the people they represent. The same data underscore related and very serious questions about whether counsel choice can be meaningful at all, much less can advance sustainable improvements in public defense, without a massive influx of new resources to support higher levels of attorney time and effort.

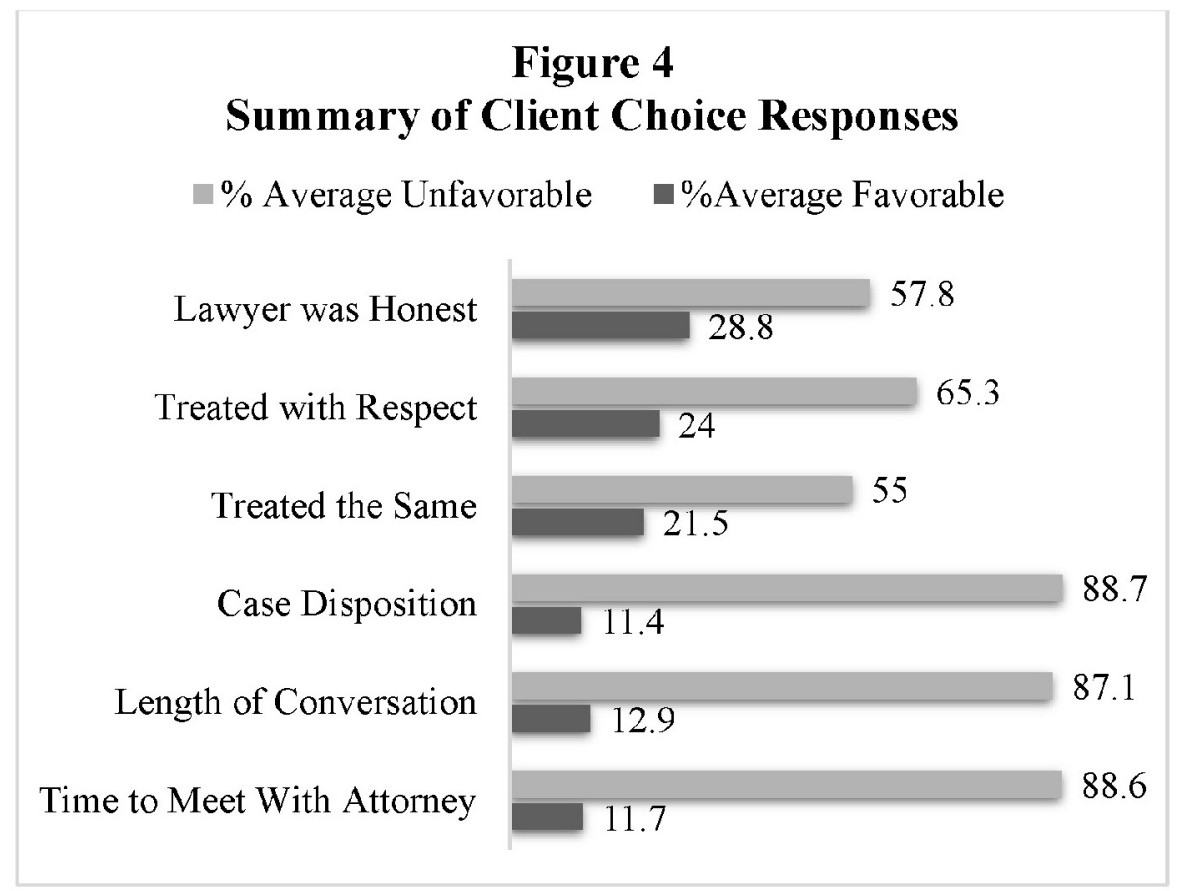

\footnotetext{
262. Id. at 37 .

263. Id. at 39 .

264. Id. at 40 .

265. Id. at 38 .
}

266. Id. at 38-39. 
The problems exposed by the Comal County counsel choice project also indicate a need for the robust use of community organizing to demand the resources necessary to support quality public defense. Absent those resources and the organizing savvy to press for their continuity as needed, counsel choice is likely to become another procedural justice strategy that reduces the impulse to form effective oppositional politics by making people feel better about navigating particular manifestations of recalcitrant power disparities. ${ }^{267}$ One way to avoid this outcome, in addition to those suggested in prior Parts of this Article, is to include people who can afford to hire private counsel and their lawyers in future studies. Including paying clients in a comparative analysis may seem like a counterintuitive strategy for avoiding the use of counsel choice as a distraction from serious resource deficits in public defense. However, comparative analysis could help to expose those resource deficits while also helping to answer critical questions regarding the information people want to have about lawyers, what they know about counsel performance, how they know it, and what difference that information makes to them. Thus, comparative analysis could fill an important knowledge gap and provide an important baseline for future research.

Another strategy for expanding and strengthening research on counsel choice is to incorporate community-based participatory research (CBPR) methods in project design and implementation. ${ }^{268}$ In contrast to the "top-down" genesis of the Comal County pilot study, in which scholars and system administrators generated and implemented the project's theoretical foundation as well as the research agenda, questions, and methods without seeking or incorporating perspectives of people who need the public defense representation, CBPR works from the ground up by building partnerships with, and responding to the expressed concerns of, members of communities affected by resource distribution disparities and other aspects of socioeconomic hierarchies. ${ }^{269}$

As shaped by significant development within the health sciences, CBPR

takes advantage of the unique strengths and insights that community and academic partners each bring to framing health problems and developing solutions. Community members, organizational representatives, and academic researchers participate in and share control over all phases of the research process . . . to increase the adoption, implementation, and maintenance of evidence-based interventions (EBIs) in communities[.] ${ }^{270}$

Thus, CBPR "represents a fundamental shift in academic researcher's views of community residents" from subjects of research to "essential partners who can energize their communities to develop effective, sustainable interventions" that

267. Cf. Silbey, supra note 53; see also Participatory Defense, supra note 26, at 1282-83.

268. See, e.g., Steven S. Coughlin et al., Overview of Community-Based Participatory Research, in Handbook of COMmunity-Based Participatory Research 1, 1-4 (Steven S. Coughlin et al. eds., 2017).

269. $I d$. at $2-3$.

270. Id. at 2 . 
improve the quality of life in those communities. ${ }^{271}$ In contrast to libertarian commitments to methodological individualism and austerity in public services, CBPR aims to "empower communities to address the root causes of inequity and identify their own problems and appropriate solutions" with a broader, more critical "ecological perspective" that incorporates analysis of multi-level factors ranging from the individual to the systemic. ${ }^{272}$

Using CBPR to conduct empirical analysis of counsel choice in the public defense context might promote deeper engagement between trained researchers, people who need public defense, and the lawyers who represent them. That deeper engagement, in contrast to methods applied in research that is generated and implemented in a more typical "top-down" fashion, can help to ensure that research questions and methods respond directly to the needs in the field. ${ }^{273} \mathrm{~A}$ CBPR approach in public defense research could offer important correctives to the design and implementation of specific projects, including future investigations of counsel choice, by encouraging broader and more productive participation by the people who are the primary focus of the research agenda.

Applying such methods in future research, scholars would do well to begin with outreach and relationship-building within that primary community, that is, with people who need public defense representation and people who provide it. There is an enormous knowledge gap in this area that should be filled in the preliminary stages with in-depth qualitiative research. ${ }^{274}$ Through participant observation, interviews, and focus groups that are designed and conducted in partnership with community members, researchers can begin to fill that knowledge gap with baseline inquiries that assess in-the-trenches perceptions and experiences on several key topics.

Those lines of inquiry should include (but are not limited to): participant experiences with and understandings of the core components or meanings of public defense representation; the definition and measures of quality in defense representation; accessibility of information about defense attorney performance; and capacities and strategies for responding with productive disruption when expectations for quality performance are unmet.

This type of in-depth research requires a great deal of time, patience, and effort. Moreover, as indicated above, comparable research should be undertaken in the context of the private defense bar. Iterative interpretation of such qualitative data in partnership with community members could generate a foundation for surveys and other instruments. A multi-year study that combines these types of investigative methods and tools with additional on-site observation, case file reviews, and other investigations into documentary evidence should yield a robust body of quantitative data and support generalizable conclusions

271. Id.

272. Id. at 2-4; see also Jean J. Schensul, Community, Culture and Sustainability in Multilevel Dynamic Systems Intervention Science, 43 Aм. J. Community Psychol. 241, 246-47 (2009) (discussing need for multilevel analysis of system interventions).

273. See Moore \& Davies, supra note 80, at 346-47 (critiquing formation of research agendas).

274. See generally CRESWell \& Plano Clark, supra note 209. 
about the exercise of counsel choice in both the private and public defense systems.

\section{CONCLUSION}

The Comal County pilot study on counsel choice is an important contribution to the field of empirical research on public defense. The study revealed strong interest among low-income people in exercising the measure of counsel choice that was offered during the year-long process of implementation and evaluation. Nevertheless, it is also important to acknowledge the ways that libertarian commitments to austerity in public services sharply limited both the meaning of counsel choice for the people who participated in the study and the ability of the study to support generalizable conclusions about the effects of counsel choice in the public defense context. As a result, the study offers a cautionary tale for proponents of counsel choice.

Future research may offer additional insight into optimal strategies for implementing and evaluating counsel choice in public defense systems. However, courts and legislators should not await the results of that research before ending overt class-based discrimination in the vindication of a fundamental constitutional right. Instead, they should release the democracy-enhancing potential that is inherent in enforcing an equal right of counsel choice for poor people. Particularly if counsel choice is accompanied by robust rights-information and community organizing strategies, exercise of this right would enable the majority of criminal defendants to increase pressure for improved attorney performance standards. Since those performance standards are central to the substantive definition of the right to counsel, improving them is a form of grassroots constitutional law formation. Such broad engagement with the generation and administration of law is likely to be critical to achieving sustainable reductions in the expansive scope and antidemocratic impact of criminal legal systems. 